\title{
Elevated Ozone Alters Soybean-Virus Interaction
}

\author{
Damla D. Bilgin, ${ }^{1}$ Mihai Aldea, ${ }^{2}$ Bridget F. O’Neill, ${ }^{3}$ Marisol Benitez, ${ }^{4}$ Min Li, ${ }^{4}$ Steven J. Clough, ${ }^{4,5}$ and \\ Evan H. DeLucia ${ }^{1,2}$ \\ ${ }^{1}$ Institute for Genomic Biology, University of Illinois at Urbana-Champaign (UIUC), 1206 W. Gregory Drive; ${ }^{2}$ Department \\ of Plant Biology, UIUC, 265 Morrill Hall, 505 South Goodwin Avenue; ${ }^{3}$ Department of Entomology, UIUC, 320 Morrill Hall, \\ 505 South Goodwin; ${ }^{4}$ Department of Crop Sciences, UIUC, 1101 W. Peabody Drive; and ${ }^{5}$ United States Department of \\ Agriculture-Agricultural Research Service, 1101 W. Peabody Drive, Urbana, IL 61801, U.S.A.
}

Submitted 3 June 2008. Accepted 10 June 2008.

\begin{abstract}
Increasing concentrations of ozone $\left(\mathrm{O}_{3}\right)$ in the troposphere affect many organisms and their interactions with each other. To analyze the changes in a plant-pathogen interaction, soybean plants were infected with Soybean mosaic virus (SMV) while they were fumigated with $\mathrm{O}_{3}$. In otherwise natural field conditions, elevated $\mathrm{O}_{3}$ treatment slowed systemic infection and disease development by inducing a nonspecific resistance against SMV for a period of 3 weeks. During this period, the negative effect of virus infection on light-saturated carbon assimilation rate was prevented by elevated $\mathrm{O}_{3}$ exposure. To identify the molecular basis of a soybean nonspecific defense response, high-throughput gene expression analysis was performed in a controlled environment. Transcripts of fungal, bacterial, and viral defenserelated genes, including $P R-1, P R-5, P R-10$, and $E D S 1$, as well as genes of the flavonoid biosynthesis pathways (and concentrations of their end products, quercetin and kaempherol derivatives) increased in response to elevated $\mathrm{O}_{3}$. The drastic changes in soybean basal defense response under altered atmospheric conditions suggest that one of the elements of global change may alter the ecological consequences and, eventually, coevolutionary relationship of plant-pathogen interactions in the future.
\end{abstract}

Additional keywords: microarray, photosynthesis, ROS, SoyFACE.

Changes in atmospheric chemistry caused by human activities are potentially reshaping the coevolutionary relationships between plants and viruses. The combustion of fossil fuels is increasing the concentration of ozone $\left(\mathrm{O}_{3}\right)$ in the atmosphere (Byrne 2001), and these increases affect myriad aspects of plant physiology and chemistry (Ainsworth and Rogers 2007; Bernacchi et al. 2006). In the past 20 years, tropospheric $\mathrm{O}_{3}$ concentration increased 0.5 to $2.5 \%$ per year and is expected to reach a global mean of $>60 \mathrm{nmol} \mathrm{mol}^{-1}$ by the year 2050 ; even today, it can episodically reach levels as high as $100 \mathrm{nmol}$ mol $^{-1}$ (Gard et al. 1998; Houghton et al. 2001).

Highly phytotoxic $\mathrm{O}_{3}$ enters the plant through stomata and is converted into reactive oxygen species (ROS), triggering a series of metabolic reactions (Kanofsky and Sima 2000; Langebartels et al. 2000; Sandermann 1996; Schraudner et al. 1996). Excess ROS can disrupt plant metabolism by causing

Corresponding author: Evan H. DeLucia; E-mail: delucia@ life.uiuc.edu

* The $\boldsymbol{e}$-Xtra logo stands for "electronic extra" and indicates that two supplemental figures and five supplemental tables are published online. irreversible damage to cell membranes, proteins, carbohydrates, and DNA (Apel and Hirt 2004). Even in the absence of visible symptoms, $\mathrm{O}_{3}$ can inhibit the growth and development of a variety of forest and grassland plants (Ashmore et al. 2007; Campbell 2007; Krupa 2003; Sandermann 1996).

Long-term exposure to elevated $\mathrm{O}_{3}$ decreased the yield of soybean and caused early senescence (Morgan et al. 2004). Oxidative bursts and rapid accumulation of ROS caused by elevated $\mathrm{O}_{3}$ not only disrupts plant metabolism but also alters gene expression (Gadjev et al. 2006; Mahalingam et al. 2006; Sharma et al. 1996). Exposure of Arabidopsis to elevated $\mathrm{O}_{3}$ modulated the abundance of 1,390 stress-related genes, including key components of salicylic acid (SA) and ethylene (ET) signaling pathways. Redox-sensitive transcription factors (TFs) and WRKY TFs also were upregulated by acute $\mathrm{O}_{3}$ fumigation (Li et al. 2006; Mahalingam et al. 2006; Tosti et al. 2006).

Plant responses to elevated $\mathrm{O}_{3}$ resemble defense responses to pathogens, involving common genes and nodes (Mittler 2006; Singh et al. 2002). By mimicking the oxidative burst generated at the early stages of hypersensitive response (HR), acute $\mathrm{O}_{3}\left(150\right.$ to $300 \mathrm{nmol} \mathrm{mol}^{-1}$ for 4 to $\left.6 \mathrm{~h}\right)$ induces HR-like localized cell death in plants, similar to the resistance $(R)$ gene-mediated host defense response (Overmyer et al. 2005; Rao and Davis 1999). Oxidative bursts caused by acute $\mathrm{O}_{3}$ treatments also affect antagonistic and synergistic interaction between the plant growth regulators jasmonic acid (JA), SA, ET, and abscisic acid (ABA). The biosynthesis of JA triggered by excess linoleic acid may attenuate SA-dependent HR and cell death (Rao et al. 2000a and b). Ozone reacts primarily with apoplastic fluid and cell membrane, which causes changes in the lipid composition and increases the production of linoleic acid (Mudd 1998). On the other hand, functional SA-signaling pathways are required for $\mathrm{O}_{3}$-induced ET biosynthesis and induction of HR-like cell death in Arabidopsis (Rao et al. 2002). An increase in the $\mathrm{O}_{3}$-induced biosynthesis of ET production boosts the biosynthesis of ABA, which regulates processes such as glucose signaling and stomatal conductance in plants (Ahlfors et al. 2004; Leon and Sheen 2003).

Ozone-induced changes in host defense response alter plant-pathogen interactions, making plants potentially resistant to obligate pathogens such as viruses (Manning and Tiedemann 1995). Viruses are intimately associated with and dependent on host cellular processes for invasion. In case of a systemic infection, virus can suppress multiple layers of innate host defenses that result in disease (Bilgin et al. 2003; Whitham et al. 2003). Any distinct change in plant gene expression directly influences its relationship with the infecting virus. There is a delicate coevolutionary relationship between 
viruses and their hosts. Their coexistence depends on the defense strategies developed by both sides, in which host gene expression plays an important role. During this antagonistic coevolution, both sides acquired new traits. It is proposed that plant viruses might have acquired their movement protein (MP) from their hosts (Roossinck 2003). Plants express proteins that function like viral MPs (Knotted1), associating with plasmadesmatal structures and facilitating the movement of RNA between plant cells (Lucas and Lee 2004; Lucas et al. 1995). On the plant side, development of posttranslational gene silencing is a unique defense strategy against viruses (Baulcombe 2004).

Plants adjust to environmental challenges by tightly and differentially regulating their transcriptome (Baker et al. 1997; Chen et al. 2002; Cushman and Bohnert 2000; YamaguchiShinozaki and Shinozaki 2006). Ozone induces oxidative bursts, which resemble the biotic elicitors that disrupt plant gene expression and metabolism (Mahalingam et al. 2006; Sharma et al. 1996). Thus, plant-pathogen interactions may be altered by rapid changes in atmospheric composition. To test the hypothesis that elevated $\mathrm{O}_{3}$ alters the relationship between plants and viruses, we used soybean and Soybean mosaic virus (SMV) as a model system. Prior to SMV infection, young soybean plants were exposed to elevated levels of $\mathrm{O}_{3}$ in the field, and the changes in SMV systemic infection, photosynthesis, antioxidant capacity, and biomass were examined. The effect of $\mathrm{O}_{3}$ on soybean gene expression, its role as an elicitor, and the changes it caused in soybean-SMV interaction were explored further in an experiment conducted in controlled-environment chambers. Analysis of the soybean gene-expression profile allowed us to identify soybean basal defense response components and to investigate the complexity of $\mathrm{O}_{3}$-induced nonspecific resistance.

\section{RESULTS}

\section{Field experiment.}

SMV-susceptible soybean plants were infected with virus under elevated $\mathrm{O}_{3}$ and ambient atmospheric conditions. Disease symptoms, including mottling, leaf curling, and stunted growth, were observed, and the systemic infection of the virus was determined by double-antibody sandwich enzyme-linked immunosorbent assay (DAS-ELISA), expressed as relative fluorescence units (RFU). The effects of elevated $\mathrm{O}_{3}$ and SMV on photosynthesis and antioxidant capacities were determined by measuring $\mathrm{A}_{\text {sat }}$ and total oxygen-radical absorbance capacity (ORAC), respectively.

Elevated $\mathrm{O}_{3}$ slowed systemic infection and the rate of disease development by SMV (Table 1). Inoculated plants had classic SMV disease symptoms of a yellow-green mosaic and leaf curling by 7 to 10 days. Samples from inoculated leaves were collected and analyzed quantitatively at $8 \mathrm{~h}$ postinfection (hpi) when no significant differences were observed between plants of different treatment (data not shown). On the following days, the magnitude of SMV infection was determined by measuring the accumulation of a viral coat protein at four timepoints for 28 days following the initial infection. Under elevated $\mathrm{O}_{3}$, the relative $\mathrm{SMV}$ titer in soybean was significantly lower for a period of 3 weeks after infection (analysis of variance [ANOVA] tables can be found in Supplementary Table 3).

SMV infection reduced the light-saturated rate of photosynthesis by approximately $10 \%$ in ambient atmospheric conditions (Table 1). There was no main effect of elevated $\mathrm{O}_{3}$. There was, however, a significant statistical interaction between SMV infection and atmospheric composition; the inhibition of photosynthesis by SMV observed under ambient conditions was eliminated in plants exposed to elevated $\mathrm{O}_{3}$ (Table 1). No effects of elevated $\mathrm{O}_{3}$ or SMV on stomatal conductance were detected (Supplementary Table 5).

Activation of the ROS scavenging network is part of oxidative stress response in plants. We used the total ORAC assay to quantify hydrophilic chain-breaking antioxidant capacity (Table 1). ROS scavenging capacity increased with time and viral infection (Table 1). The treatment modulated the effect of SMV on ROS scavenging capacity but was unaffected by exposure to elevated $\mathrm{O}_{3}$.

Across all treatments, SMV infection caused a $42 \%$ reduction in aboveground biomass and yield of soybean (Table 1). The decrease in vegetative biomass caused by SMV infection did not significantly differ in $\mathrm{O}_{3}$ treatments. The pod yield decreased by approximately $55 \%$ for SMV-infected plants (Table 1). There was no indication of an interactive effect of SMV infection with changes in the composition of the atmosphere.

\section{Growth chamber experiments.}

A controlled-environment experiment was conducted to more closely examine the interactive effects of SMV infection and elevated $\mathrm{O}_{3}$ on soybean gene transcription, flavonoid content, and ROS formation. The Affymetrix oligonucleotide-based GeneChip Soybean Genome Array that represents 35,611 soy-

Table 1. Summary of significance analysis of SoyFACE experiment ${ }^{\mathrm{Z}}$

\begin{tabular}{|c|c|c|c|c|c|c|}
\hline \multirow[b]{2}{*}{ Measurements } & \multirow[b]{2}{*}{ Significance } & \multirow[b]{2}{*}{ Day } & \multicolumn{2}{|c|}{ Ambient } & \multicolumn{2}{|c|}{$\mathbf{O}_{3}$} \\
\hline & & & $-\mathbf{V}$ & $+\mathrm{V}$ & $-\mathbf{V}$ & $+\mathrm{V}$ \\
\hline Virus Infection & $\mathrm{T}, \mathrm{V}, \mathrm{T} \times \mathrm{V}$ & 7 & $0.07(0.05)$ & $0.45(0.05)$ & $0.07(0.05)$ & $0.24(0.05)$ \\
\hline \multirow[t]{3}{*}{ DAS-ELISA (RFU) } & $\mathrm{D}, \mathrm{D} \times \mathrm{V}$ & 14 & $0.05(0.13)$ & $1.45(0.13)$ & $0.05(0.13)$ & $0.97(0.13)$ \\
\hline & & 21 & $0.06(0.12)$ & $1.45(0.12)$ & $0.06(0.12)$ & $1.04(0.12)$ \\
\hline & & 28 & $0.04(0.47)$ & $1.91(0.47)$ & $0.05(0.47)$ & $1.07(0.47)$ \\
\hline Antioxidant Capacity & $\mathrm{D}, \mathrm{V}$ & 7 & $5.6(1.2)$ & $5.7(0.5)$ & $5.8(0.4)$ & $6.1(0.2)$ \\
\hline \multirow{2}{*}{ ORAC (Trolox units) } & $\mathrm{T} \times \mathrm{V}$ & 14 & $6.9(0.3)$ & $6.4(1.0)$ & $7.0(0.2)$ & $7.4(0.6)$ \\
\hline & & 21 & $6.6(0.7)$ & $6.9(0.5)$ & $7.1(0.8)$ & $7.6(0.9)$ \\
\hline Photosynthesis & $\mathrm{D}, \mathrm{T}, \mathrm{D} \times \mathrm{T}$ & 4 & $19.1(2.8)$ & $18.8(2.7)$ & $21.9(2.8)$ & $25.7(2.8)$ \\
\hline \multirow[t]{4}{*}{$A_{\text {sat }}\left(\mu \mathrm{mol} \mathrm{m} \mathrm{m}^{-2} \mathrm{~s}^{-1}\right)$} & $\mathrm{T} \times \mathrm{V}$ & 8 & $23.8(2.8)$ & $25.1(2.8)$ & $25.1(2.8)$ & $25.7(2.8)$ \\
\hline & & 16 & $23.9(2.8)$ & $19.0(2.8)$ & $22.9(2.8)$ & $21.6(2.7)$ \\
\hline & & 22 & $23.8(2.9)$ & $17.3(2.9)$ & $18.6(2.9)$ & $20.6(2.9)$ \\
\hline & & 41 & $16.0(2.9)$ & $15.4(2.9)$ & $16.3(3.0)$ & $14.2(3.0)$ \\
\hline Vegetative mass (g) & $\mathrm{V}$ & 82 & $87.2(8.0)$ & $45.8(8.0)$ & $87.6(8.0)$ & $50.1(8.0)$ \\
\hline Pod mass (g) & $\mathrm{V}, \mathrm{T}$ & 82 & $28.6(1.9)$ & $10.3(1.9)$ & $24.1(1.9)$ & $13.6(1.9)$ \\
\hline
\end{tabular}

z The measurements were done weekly after Soybean mosaic virus (SMV) infection. Plants were assayed for SMV by double-antibody sandwich-enzymelinked immunosorbent assay (DAS-ELISA) in relative fluorescence units (RFU). Total antioxidant capacity was measured by oxygen-radical absorbance capacity (ORAC) in Trolox units, up to 21 days after inoculation. Net photosynthesis $\left(\mathrm{A}_{\text {sat }}\right)$ was measured at saturating light intensity. The dry weight of leaves and stems (vegetative mass) and pods were measured at the end of the season. Each value is a mean ( $n=4)$ followed by the one standard error. Only statistically significant values or interactions $(P<0.05)$ for overall measurements were designated as $\mathrm{D}=\mathrm{day}, \mathrm{T}=$ treatment, and $\mathrm{V}=$ virus. 
bean transcripts was used to determine the changes in transcript levels. Significant gene lists were obtained after applying a cutoff false discovery rate (FDR) of $<0.01$.

Viral infection and elevated $\mathrm{O}_{3}$, singly and in combination, caused a significant change in the transcript levels of 2,280 genes at $8 \mathrm{hpi}$ and 1,191 genes at $72 \mathrm{hpi}$ (Fig. 1). Exposure to $\mathrm{O}_{3}$ elicited substantially more genes at $8 \mathrm{hpi}$ than viral infection or the $\mathrm{O}_{3}$-plus-SMV treatment. The genes regulated by exposure to $\mathrm{O}_{3}$ alone decreased by $72 \mathrm{hpi}$. The number of genes regulated by all the treatments increased at the later timepoint (Fig. 1).

SMV infection alone did not affect the transcription of as many genes as elevated $\mathrm{O}_{3} ; 219$ transcripts were solely regulated by SMV infection (Fig. 1). A comparison with the $\mathrm{Na}-$ tional Center for Biotechnology Information (NCBI) nonredundant database revealed that 82 of these genes coded for proteins with unknown functions. Multiple Kunitz-type trypsin inhibitors $(K T I)$ were downregulated $8 \mathrm{~h}$ after SMV infection. In contrast, elevated $\mathrm{O}_{3}$ increased the levels of $K T I$ transcripts. Levels of transcripts related to genes regulating circadian rhythm, such as late elongated hypocotyl ( $L H Y)$ and Arabidopsis pseudoresponse regulator 5 (APRR5) soybean homologs, also were increased by virus infection (Supplementary Table 1).

Soybean plants responded to elevated $\mathrm{O}_{3}$ and SMV infection by enhancing the transcript levels of several genes coding antioxidant enzymes. Ascorbate peroxidase was increased at 8 hpi in response to elevated $\mathrm{O}_{3}$ and the $\mathrm{O}_{3}$-plus-SMV treatment. Multiple glutathione S-transferase (GST) transcripts increased in response to SMV and elevated $\mathrm{O}_{3}$ (Table 2). GST7, GST15, and GST18 transcripts increased only in the presence of elevated $\mathrm{O}_{3}$ at $72 \mathrm{hpi}$. In contrast, GST12 and

Table 2. Selection of soybean transcripts that were differentially expressed by Soybean mosaic virus (SMV) infection, elevated $\mathrm{O}_{3}$, and combination of $\mathrm{O}_{3}$ plus SMV infection at 8 and $72 \mathrm{hpi}$; ambient mock treatment was used as a control

\begin{tabular}{|c|c|c|c|c|c|c|c|c|}
\hline \multirow[b]{3}{*}{ Gene description } & \multirow[b]{3}{*}{ Affymetrix ID } & \multirow[b]{3}{*}{ TIGR TC ${ }^{y}$} & \multicolumn{6}{|c|}{ Transcript fold change $\left(\log _{2}\right)$, FDR $P$-value $<0.01$} \\
\hline & & & \multicolumn{3}{|c|}{8 hpi } & \multicolumn{3}{|c|}{72 hpi } \\
\hline & & & SMV & $\mathbf{O}_{3}$ & $\mathrm{SMV}+\mathrm{O}_{3}$ & SMV & $\mathbf{O}_{3}$ & $\mathrm{SMV}+\mathrm{O}_{3}$ \\
\hline \multicolumn{9}{|l|}{ Oxidative stress related genes } \\
\hline Alternative oxidase & Gma.1439.1.S1_at & TC217347 & - & - & 1.96 & - & - & - \\
\hline Ascorbate peroxidase & GmaAffx.44716.1.A1_at & BI969342 & - & 1.13 & - & - & - & - \\
\hline Ascorbate oxidase precursor & GmaAffx.47157.1.A1_at & TC204959 & - & 1.26 & 2.26 & - & - & - \\
\hline GSTX_SOYBN & GmaAffx.19480.1.S1_at & TC214400 & 2.11 & - & 2.23 & - & 1.11 & 1.13 \\
\hline GSTX6_SOYBN & GmaAffx.88762.1.S1_at & TC214058 & 1.43 & - & 2.31 & - & 2.50 & 1.91 \\
\hline GST 15 & Gma.2593.1.S1_s_at & TC215837 & - & - & 3.00 & - & 3.40 & 2.80 \\
\hline Peroxidase precursor & GmaAffx.92917.1.S1_s_at & TC215016 & - & 2.04 & 1.58 & - & - & - \\
\hline SRG1 (senescence related gene1) oxidoreductase & Gma.8240.1.S1_at & TC231312 & - & - & - & - & 1.52 & 1.20 \\
\hline \multicolumn{9}{|l|}{ Defense-related genes } \\
\hline PR1a precursor & GmaAffx.42847.2.S1_at & TC227432 & - & 2.41 & 2.92 & - & 3.98 & 4.43 \\
\hline PR5 thaumatin-like protein & Gma.2821.2.S1_a_at & TC226940 & - & 1.13 & 1.56 & - & 3.02 & 2.39 \\
\hline PR10-like protein & Gma.6999.1.S1_x_at & TC227429 & 2.04 & 1.11 & 2.99 & - & 4.08 & 3.50 \\
\hline PR10-like protein (stress-induced protein SAM22) & Gma.6999.3.S1_s_at & TC224834 & 2.79 & 1.38 & 3.33 & - & 3.44 & 3.18 \\
\hline EDS1 putative & GmaAffx.80842.1.S1_at & BE440732 & - & 1.00 & 1.64 & - & 1.43 & 1.63 \\
\hline COI1 & GmaAffx.21596.1.S1_at & BE329784 & - & 1.37 & - & - & - & - \\
\hline Disease-resistance gene (RPP13-like) & GmaAffx.57686.1.S1_at & AW597616 & - & - & 1.54 & - & - & - \\
\hline Disease-resistance gene $(R P M I)$ & GmaAffx.67437.1.S1_at & TC224491 & - & - & 1.75 & - & - & - \\
\hline TIR-NBS ${ }^{\mathrm{z}}$ disease resistance-like protein & GmaAffx.92922.1.S1_at & TC208227 & - & - & 1.73 & _- & _- & _- \\
\hline NDR1/HIN1-like protein 3 (NHL3) & Gma.9397.1.S1_at & CA802074 & - & - & 1.62 & - & - & - \\
\hline Disease resistance-responsive family protein & Gma.4332.1.S1_at & TC215635 & - & - & - & - & 1.79 & 1.98 \\
\hline DRR4_PEA disease-resistance response & GmaAffx.93611.1.S1_s_at & TC208219 & - & - & - & - & 1.15 & 1.34 \\
\hline Disease resistance-like gene ( $C f-4 / 9)$ & Gma.3351.1.S1_at & BQ454138 & - & - & - & - & 1.16 & 1.13 \\
\hline Endo-1,3-beta-glucanase & GmaAffx.86629.1.S1_at & TC228694 & - & - & 1.14 & _- & 2.12 & 1.75 \\
\hline Chitinase & Gma.3702.1.S1_at & TC228060 & - & 1.63 & 2.7 & - & 2.79 & 2.51 \\
\hline CHIT1_tulip bulb chitinase-1 (TBC-1) & GmaAffx.89972.1.S1_s_at & TC228060 & - & 1.46 & 2.42 & - & 2.51 & 2.05 \\
\hline Acidic chitinase & GmaAffx.494.1.S1_at & TC216469 & - & - & 1.46 & - & 2.17 & 1.86 \\
\hline \multicolumn{9}{|l|}{ Ethylene signaling related genes } \\
\hline Transcription factor EIL1 & GmaAffx.13724.1.S1_s_at & TC214361 & - & - & - & 1.98 & 1.84 & 1.68 \\
\hline Transcription factor EIL2 & GmaAffx.86555.1.S1_s_at & TC214228 & - & - & - & 2.64 & 2.53 & 2.48 \\
\hline EBF1 (EIN3-BINDING F BOX PROTEIN 1) & GmaAffx.54144.1.S1_at & TC212384 & - & - & - & 2.79 & 2.67 & 2.64 \\
\hline \multicolumn{9}{|l|}{ Jasmonic acid signaling related genes } \\
\hline Phospholipase A2 & Gma.7515.1.S1_at & TC207273 & - & 1.746 & - & - & - & - \\
\hline Lipoxygenase LOX1 & GmaAffx.45573.1.S1_at & TC233575 & - & - & - & 2.27 & 2.09 & 1.78 \\
\hline Lipoxygenase (AtLox2) & Gma.2382.1.S1_s_at & TC207342 & - & - & 1.72 & - & 1.26 & 1.78 \\
\hline Allene oxide synthase & Gma.6281.3.S1_at & CA800304 & - & - & - & 1.94 & 1.75 & 1.82 \\
\hline 12-oxophytodienoate reductase & GmaAffx.6142.1.S1_at & TC228335 & 1.16 & - & - & - & - & - \\
\hline \multicolumn{9}{|l|}{ NAC transcription factors } \\
\hline NAC domain protein NAC1 & GmaAffx.32328.1.A1_at & TC216429 & - & -1.90 & -1.44 & - & - & - \\
\hline NAC domain protein NAC1 & Gma.4643.1.S1_at & TC216430 & - & -1.69 & -1.55 & - & - & - \\
\hline NAC domain protein NAC2 & Gma.4774.2.S1_at & TC215443 & -1.53 & -1.47 & -1.33 & - & - & 1.04 \\
\hline NAC domain protein NAC3 & GmaAffx.57970.1.S1_at & TC215245 & -1.61 & -2.27 & -2.16 & - & - & - \\
\hline NAC domain protein NAC4 & Gma.5331.1.S1_at & TC215244 & -1.23 & -2.84 & -1.79 & - & - & - \\
\hline NAC family protein & GmaAffx.90028.1.S1_s_at & TC205356 & -1.64 & -1.59 & -1.22 & - & - & - \\
\hline NAC family protein & Gma.5519.1.S1_at & TC205356 & -1.60 & -1.63 & -1.33 & - & - & 1.32 \\
\hline ANAC062; transcription factor & GmaAffx.32877.1.S1_at & TC234989 & - & - & - & 1.13 & 1.37 & 1.15 \\
\hline ANAC 017 ; transcription factor & GmaAffx.75215.1.S1_at & TC234607 & - & - & - & - & 1.08 & - \\
\hline
\end{tabular}

\footnotetext{
${ }^{y}$ TIGR TC $=$ The Institute for Genomic Research tentative consensus.
}

${ }^{\mathrm{z}}$ TIR-NBS $=$ toll interleukin 1 receptor-nucleotide binding site. 
GST14 transcripts accumulated in response to SMV infection with or without elevated $\mathrm{O}_{3}$ at the early timepoint. Several peroxidase genes responded to both stresses. In particular, class III peroxidases were increased by SMV infection at the early timepoint (Table 2).

The accumulation of transcripts for several antioxidant enzymes suggested that ROS was formed in response to elevated $\mathrm{O}_{3}$, SMV infection, and the $\mathrm{O}_{3}$-plus-SMV treatment. The spatial production of $\mathrm{H}_{2} \mathrm{O}_{2}$ and $\mathrm{O}_{2}{ }^{--}$in the foliar tissue following exposure to $\mathrm{SMV}$ alone or in combination with elevated $\mathrm{O}_{3}$ was determined in a subsequent growth-chamber experiment. The presence of a brown precipitate in leaves infiltrated with diaminobenzidine (DAB) indicated that virus infection caused $\mathrm{H}_{2} \mathrm{O}_{2}$ to accumulate in dense patches throughout the leaf mesophyll (Fig. 2B). Exposure to elevated $\mathrm{O}_{3}$ alone caused localized bursts of $\mathrm{H}_{2} \mathrm{O}_{2}$ production (Fig. 2C). The pattern of accumulation of $\mathrm{H}_{2} \mathrm{O}_{2}$ in the combination treatments $\left(\mathrm{O}_{3}\right.$ plus SMV) was similar to leaves exposed only to SMV infection, but the intensity of the response was lower (Fig. 2D). Exposure to elevated $\mathrm{O}_{3}$, singly or in combination with SMV infection, caused localized accumulation of $\mathrm{O}_{2}{ }^{--}$, evident as a blue precipitate (Fig. 2F, G, and $\mathrm{H}$ ). The number of spots and the intensity of nitroblue tetrazolium (NBT) accumulation were strongest in leaves exposed simultaneously to $\mathrm{O}_{3}$ and virus infection (Fig. 2H).

Flavonoid biosynthesis gene transcripts accumulated at both timepoints with a maximum up to 10.6-fold in the presence of $\mathrm{O}_{3}$; however, by $72 \mathrm{hpi}$, these particular flavonoid biosynthesis genes were not affected by SMV infection (Fig. 3). Elevated $\mathrm{O}_{3}$ and the $\mathrm{O}_{3}$-plus-SMV treatments increased the transcript levels of phenylalanine ammonia-lyase $(P A L)$, 4-coumarate:CoA ligase $(4 C L)$, chalcone synthase $(C H S)$, chalcone reductase $(C H R)$, chalcone isomerase $(C H I)$, isoflavone synthase (IFS), isoflavone reductase (IFRl), and 2-hydroxyisoflavanone dehydratase (HID) (Fig. 3 and Supplementary Table 2).

The analysis of flavonoids by liquid chromatography mass spectrometry (LC/MS) revealed that $\mathrm{O}_{3}$ treatment and virus infection caused significant changes in flavonoid concentrations in soybean leaves (Table 3 and Supplementary Fig. 1). Quercetin triglycoside was significantly greater in $\mathrm{O}_{3}$-plusvirus samples than virus treatment alone. The quercetin triglycoside amount did not change with time. Kaempherol triglycoside increased over time in ambient conditions and its amount was significantly higher in virus treatment than $\mathrm{O}_{3}$ treatment at early timepoint. This difference disappeared by $72 \mathrm{~h}$. Virus infection decreased the production of methyl quercetin triglycoside; however, when the plants were pre-exposed to elevated $\mathrm{O}_{3}$, the decrease was not observed. Quercetin diglycoside concentration was significantly higher in $\mathrm{O}_{3}$-plus-SMV-infected plants than the virus-infected plants under ambient conditions at 8 hpi. Methyl quercetin diglycoside increased only when
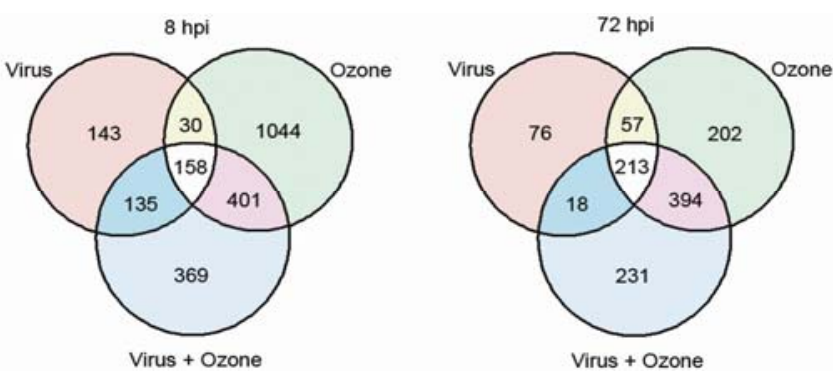

Fig. 1. Venn diagram depicting the number of soybean transcripts showing common or differential expression in response to elevated $\mathrm{O}_{3}$, Soybean mosaic virus (SMV), and the combination of elevated $\mathrm{O}_{3}$ plus SMV at 8 and $72 \mathrm{~h}$ postinfection (hpi). plants were infected with virus in the presence of elevated $\mathrm{O}_{3}$ (Table 3). The kaempherol diglycoside amount was significantly less than mock-inoculated plants in ambient conditions when both $\mathrm{O}_{3}$ and SMV infection were applied. Genistein malonylhexose and kaempherol aglycone increased by time in $\mathrm{O}_{3}$-treated samples. They were significantly higher in $\mathrm{O}_{3}$ treated plants than virus-infected plants in ambient conditions at 72 hpi.

In addition to genes in flavonoid biosynthesis, defense response genes induced by SA, JA, and ET were differentially regulated by elevated $\mathrm{O}_{3}, \mathrm{SMV}$, and the $\mathrm{O}_{3}$-plus-SMV treatment. Isochorismate synthase (ICS) transcript levels increased at an early timepoint and PAL gene transcripts increased at a later timepoint. ICS and $P A L$ are required to synthesize SA for defense. Pathogenesis-related 1 and 10 (PR-1 and PR-10), thaumatin-like $P R-5$, and enhanced disease susceptibility (EDS1) transcripts were increased up to fourfold $\left(\log _{2}\right)$ by elevated $\mathrm{O}_{3}$ treatment (Table 2). The transcript levels of these genes were verified by real-time reverse-transcribed polymerase chain reaction (RT-PCR) (Supplementary Fig. 2 and Supplementary Table 4). The direction of the response of genes measured by real-time RT-PCR and microarray were similar but the magnitude of the response was greater when meas-
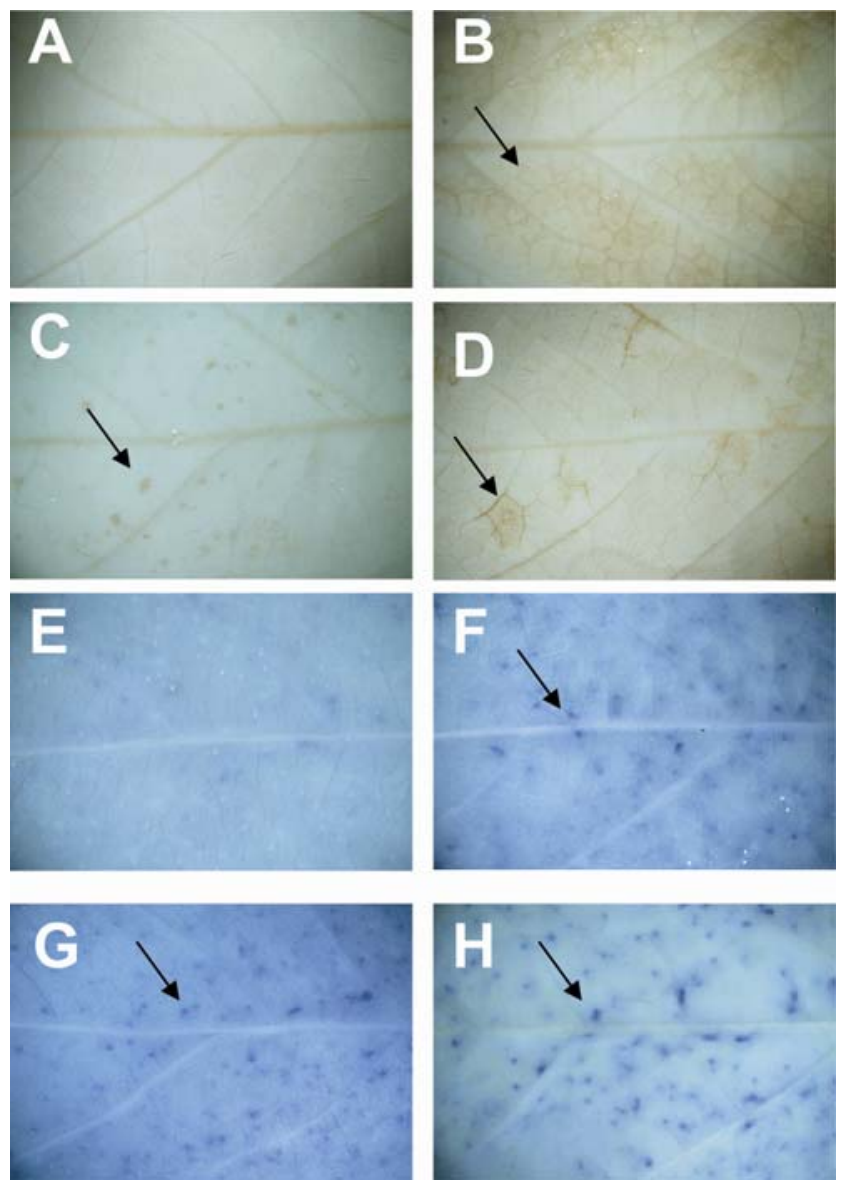

Fig. 2. Accumulation of $\mathrm{H}_{2} \mathrm{O}_{2}$ and superoxide in soybean plants grown in temperature-controlled growth chambers. To observe the effect of Soybean mosaic virus (SMV) systemic infection and elevated $\mathrm{O}_{3}$, the top soybean leaves were infiltrated with diaminobenzidine (DAB) and nitroblue tetrazolium (NBT) at 7 days postinoculation. A through D, Staining for $\mathrm{H}_{2} \mathrm{O}_{2}$ accumulation with DAB. A, Mock-inoculated plants in ambient conditions; $\mathbf{B}, \mathrm{SMV}$-infected plants in ambient condition; $\mathbf{C}$, elevated $\mathrm{O}_{3}$-treated plants; D, elevated $\mathrm{O}_{3}$-treated and SMV-infected plants. $\mathbf{E}$ through $\mathbf{H}$, Staining for superoxide with NBT. E, Mock-inoculated plants in ambient condition; F, SMV-infected plants in ambient condition; G, elevated $\mathrm{O}_{3^{-}}$ treated plants; $\mathbf{H}$, elevated $\mathrm{O}_{3}$-treated and SMV-infected plants. 
ured by real-time RT-PCR. Transcripts related to a large number of 1,3- $\beta$-glucanase, endo-1,4- $\beta$-glucanase, and chitinase genes were also increased in elevated $\mathrm{O} 3$ and the $\mathrm{O} 3$ plus-SMV treatment (Table 2). The transcript levels of 10 different glucanase genes and 7 chitinase genes were increased by elevated $\mathrm{O}_{3}$ (Table 2 ).

Transcript levels for genes related to ET signaling were greater in response to all treatments. ET is perceived by the membrane-bound histidine kinase receptor ETR1 and triggers defense and development-related responses (Luthen et al 2007). At 72 hpi, six transcripts representing four ET-regulated TFs such as ethylene-insensitive 3 (EIN3) and EIN3-like 1 and 2 homologs (EIL1 and EIL2) increased in unison (Table 2). Also, elevated $\mathrm{O}_{3}$ increased the transcription of several brassinosteroid (BR) and auxin-signaling-related genes.

Transcript levels of genes in the octadecanoid pathway leading to the production of JA were increased by $\mathrm{O}_{3}$ and the $\mathrm{O}_{3}$ plus-SMV treatment, especially at 72 hpi. Phospholipase A2 transcripts increased by elevated $\mathrm{O}_{3}$ at an early timepoint. The expression of lipoxygenase 1 ( $L O X 1)$ increased in response to all treatments whereas soybean $L O X 2$ homolog responded only to elevated $\mathrm{O}_{3}$ and the $\mathrm{O}_{3}$-plus-SMV treatment (Table 2). Lipoxygenases also function in the hydroperoxide lyase pathway; however, there were no significant changes in hydroperoxide lyase $(H P L)$ transcript levels. Transcripts of allene oxide synthase $(A O S)$ that leads to JA biosynthesis were increased in response to all the treatments at $72 \mathrm{hpi}$.

TFs play a central role in orchestrating the genomic responses to external stimuli. Exposure to elevated $\mathrm{O}_{3}$ decreased transcript levels of $N A C$ TFs. In all, 32 transcripts that represent 15 different $N A C$ TFs decreased more than twofold $\left(\log _{2}\right)$ by elevated $\mathrm{O}_{3}$ and the $\mathrm{O}_{3}$-plus-SMV treatment (Table 2). Five of these genes also were decreased by SMV infection at an early timepoint. Alternatively, two NAC TFs that showed homology to Arabidopsis ANACO62 and ANAC017 had higher transcript levels at 72 hpi.

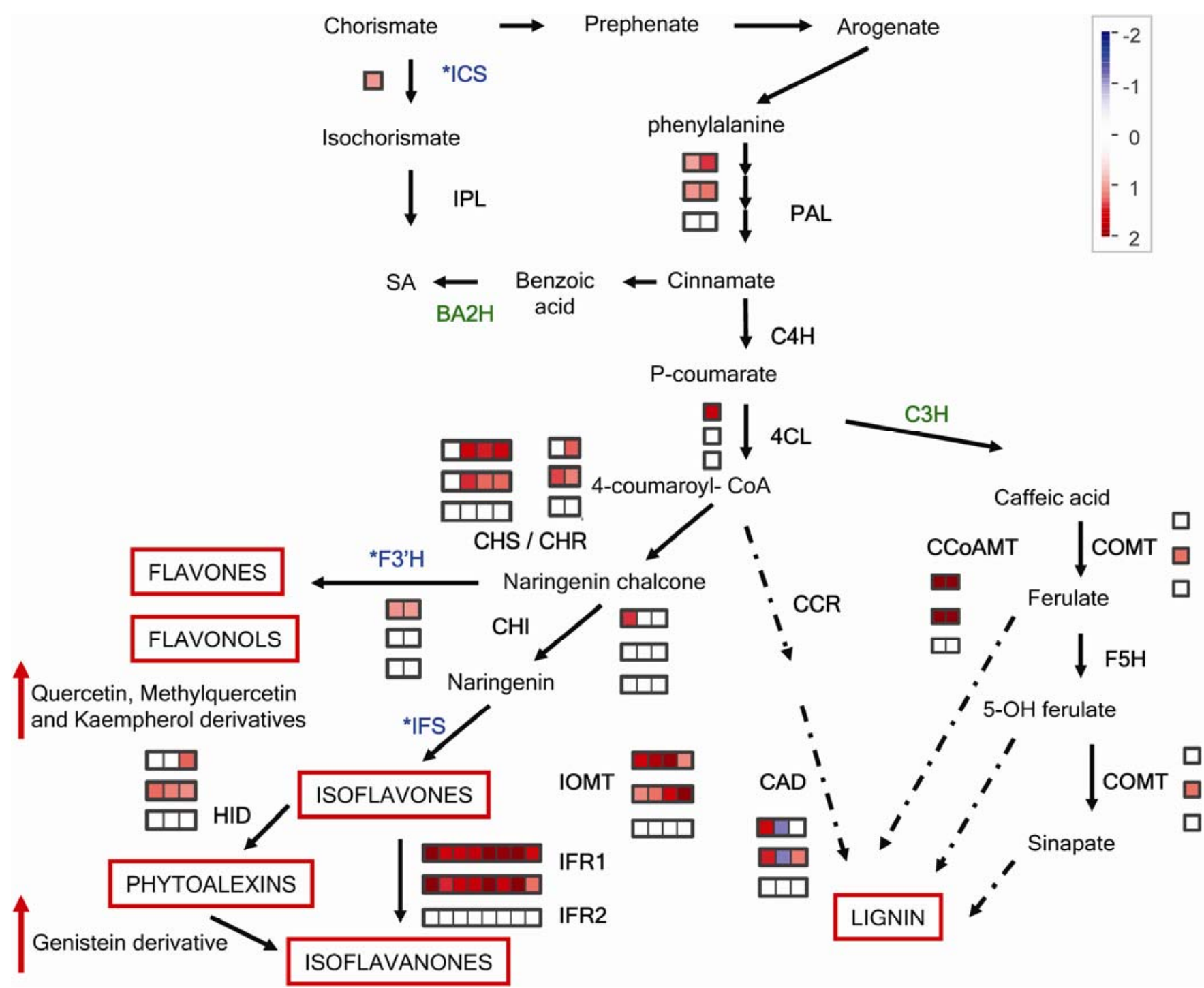

Fig. 3. Graphical representation of significantly differentiated gene transcripts in phenylpropanoid metabolism in response to elevated $\mathrm{O}_{3}$, elevated $\mathrm{O}_{3}$ plus Soybean mosaic virus (SMV), and SMV treatments at $72 \mathrm{~h}$ postinfection (hpi). Each box corresponds to one soybean transcript. For each gene, the upper block of squares represents genes regulated by elevated $\mathrm{O}_{3}$ treatment, the middle block represents genes regulated by $\mathrm{O}_{3}$ plus $\mathrm{SMV}$, and the lower block represents genes regulated by SMV infection. The genes marked with an asterisk were detected only at 8 hpi. No annotated expressed sequence tags exist in soybean public databases for the genes in green. Values for gene regulation are expressed by color intensity, where upregulation is indicated by shades of red and downregulation by shades of blue. Abbreviations: benzoic acid 2-hydroxylase (BA2H), caffeic acid $O$-methyltransferase (COMT), caffeoyl-CoA 3-Omethyltransferase (CCOAMT), chalcone isomerase (CHI), chalcone reductase (CHR), chalcone synthase (CHS), cinnamyl alcohol dehydrogenase (CAD), 4coumarate:CoA ligase (4CL), 2-hydroxyisoflavanone dehydratase (HID), isoflavone synthase (IFS), isoflavone reductase (IFR1), isochorismate synthase (ICS), p-coumarate 3 hydroxylase $(\mathrm{C} 3 \mathrm{H})$, and phenylalanine ammonia-lyase (PAL). 


\section{DISCUSSION}

The response of a plant to a given stress is governed by its genetic background. To study the changes in the soybeanSMV interaction, we used an SMV-susceptible but moderately $\mathrm{O}_{3}$-tolerant soybean line (Glycine max cv. Pioneer 93B15). As a result of long-term elevated $\mathrm{O}_{3}$ treatment, the soybean-SMV interaction was altered and a nonspecific defense response was induced. The induced response slowed systemic infection by SMV and reduced its negative effect on photosynthesis. However, the nonspecific defense response induced by $\mathrm{O}_{3}$ did not provide life-time protection, and plants infected with SMV had typical disease symptoms and lower end-of-season biomass and yield (Table 1). Analysis of transcript levels by highthroughput gene expression profiling provided possible explanations for the mechanisms of nonspecific defense response.

Ozone enters the plant through stomata and dissociates in the apoplast as a function of endogenous hydroxyl ion concentration (Rao et al. 2000a and b). It generates ROS such as $\mathrm{H}_{2} \mathrm{O}_{2}$ and $\mathrm{O}_{2}{ }^{\circ-}$ and alters redox balance (Mano 2002). Whether the $\mathrm{O}_{3}$ treatment is acute ( 150 to $300 \mathrm{nmol} \mathrm{mol}^{-1}$ for 4 to $6 \mathrm{~h}$ ) or chronic $\left(<100 \mathrm{nmol} \mathrm{mol}^{-1}\right.$ for months), the apoplast soon becomes saturated with ROS and causes activation or accumulation of signaling intermediates, such as SA, JA, and ET, and eventually induces a defense response (Apel and Hirt 2004; Heath 2007; Kangasjarvi et al. 2005). The production of ROS is an important initial determinant of plant-pathogen interactions, and its intensity and duration differ in host-incompatible and host-compatible interactions (Bolwell et al. 2002; Scheel 2002). In plants, it has been shown that various biotic and abiotic stress response pathways share common nodes (Lee et al. 2006; Mazarei et al. 2007; Sohn et al. 2006). In our experiments, exposure to elevated levels of $\mathrm{O}_{3}$ mimicked the effect of pathogen infection and the defense response induced by elevated $\mathrm{O}_{3}$ improved resistance against $\mathrm{SMV}$ for a period of 3 weeks (Table 1). Even though the soybean line was moderately tolerant to $\mathrm{O}_{3}$, plants were sensitive enough that the $\mathrm{O}_{3}$ treatment transiently enhanced SMV resistance, possibly by modulating defense-related gene expression levels and the concentration of individual flavonoids.

Individual viral, bacterial, and fungal infection strategies are diverse; therefore, each plant-pathogen interaction under elevated $\mathrm{O}_{3}$ may show different characteristics (Manning and Tiedemann 1995). Similarly, acute ozone treatment (150 to $300 \mathrm{nmol} \mathrm{mol}^{-1}$ ) protected tobacco from Tobacco mosaic virus (TMV) and increased tolerance of Arabidopsis thaliana to Pseudomonas syringae (Sandermann 2000). However, Peanut stunt virus (PSV) infection and sustained levels of $\mathrm{O}_{3}$ treatment had additive effects on $\mathrm{O}_{3}$-sensitive Trifolium repens (Heagle et al. 1992).
There are strong similarities between defenses induced by elevated $\mathrm{O}_{3}$ and systemic acquired resistance (SAR) (Durrant and Dong 2004; Kotchoni and Gachomo 2006). During the response to $\mathrm{SAR}$ and $\mathrm{O}_{3}$, microbursts of ROS may activate defense responses throughout the plant. The transcription of many defense genes involved in SAR is activated by the longterm exposure to elevated $\mathrm{O}_{3}$. For example, SA plays a major role in HR resistance and SAR and may be synthesized by two pathways that involve $P A L$ and ICS (Kachroo and Kachroo 2007; Wildermuth et al. 2001). In Arabidopsis, SA biosynthesis and ICS transcript level started to increase within $3 \mathrm{~h}$ in response to acute $\mathrm{O}_{3}$ treatment (Ogawa et al. 2007). There was a slight increase in PAL2 transcript but not in PAL1. In our study, elevated $\mathrm{O}_{3}$ increased the transcript of ICS and $P A L$ genes in soybean at early and later timepoints, respectively. The increase in transcript levels of these genes may cause increases in SA production. The increase in $P R-1$ gene transcript (TC227431; greater than fourfold; $\log _{2}$ ) may have played a role in defense against SMV together with several SA-regulated defense genes such as PR5 and EDS1 homologs. Among PR genes, the transcript level of a soybean $P R$-10-like gene (TC227429) increased approximately fourfold $\left(\log _{2}\right)$. The $P R$ 10 gene from Capsicum annuum was induced after TMV infection and was shown to have ribonuclease activity against TMV RNA (Park et al. 2004).

Another defense pathway induced by elevated $\mathrm{O}_{3}$ with or without SMV infection is phenylpropanoid biosynthesis (Fig. 3 and Supplementary Fig. 4). Flavonoids have antioxidant capacity and may function by inhibiting ROS-producing enzymes such as NADPH oxidase, cyclooxygenase, lipoxygenase, and chelating trace elements involved in free radical production (Brown et al. 1998; Korkina 1997, 2007; Pietta 2000; Ursini et al. 1994). Oxidative bursts caused by elevated $\mathrm{O}_{3}$ lead to ROS formation that may exceed the apoplastic antioxidative capacity. Ozone-induced excess ROS formation shows similarity to HR and activates defense response and cell death via SA, ET, and JA signaling pathways (Kangasjarvi et al. 2005; Rao and Davis 2001; Tuominen et al. 2004). In susceptible plants, the activation of a phenylpropanoid pathway may affect SA levels and basal defense response against pathogens.

Many secondary metabolites that are part of the defense response against pathogens are derived from multiple branches of the phenylpropanoid pathway, including flavonols, isoflavonoid phytoalexins, and lignins. Protein engineering approaches were successfully used to construct multienzyme biosynthesis pathways in nonlegume plants to increase their pathogen resistance (Shadle et al. 2003; Tian et al. in press). Acute $\mathrm{O}_{3}$ exposure increased the transcript of stilbene synthase (STS) and CHS genes in pine, grapevine, and Arabidopsis (Chiron et al. 2000; Schubert et al. 1997; Tosti et al. 2006).

Table 3. Flavonoids of noninfected and infected soybean plants in ambient and elevated $\mathrm{O}_{3}$ conditions ${ }^{\mathrm{a}}$

\begin{tabular}{|c|c|c|c|c|c|c|c|c|}
\hline Flavonoids & $\begin{array}{c}\text { Quercetin } \\
\text { triglycoside }\end{array}$ & $\begin{array}{l}\text { Kaempferoltri } \\
\text { glycoside }\end{array}$ & $\begin{array}{l}\text { Methylquercetin } \\
\text { triglycoside }\end{array}$ & $\begin{array}{l}\text { Quercetin } \\
\text { diglycoside }\end{array}$ & $\begin{array}{l}\text { Methylquercetin } \\
\text { diglycoside }\end{array}$ & $\begin{array}{l}\text { Kaempherol } \\
\text { diglycoside }\end{array}$ & $\begin{array}{c}\text { Genistein } \\
\text { malonyl hexose }\end{array}$ & $\begin{array}{l}\text { Kaempherol } \\
\text { aglycone }\end{array}$ \\
\hline \multicolumn{9}{|c|}{8 hours postinoculation (hpi) } \\
\hline A & $17.99 \pm 4.1(\mathrm{ab})$ & $33.95 \pm 5.6(\mathrm{bc})$ & $23.5 \pm 4.09(\mathrm{ab})$ & $63.25 \pm 12.8(\mathrm{ab})$ & $42.89 \pm 6.82(\mathrm{ab})$ & $52.47 \pm 7.5(\mathrm{ab})$ & $9.04 \pm 8.8(\mathrm{c})$ & $0 \pm 3.9(b)$ \\
\hline $\mathrm{V}$ & $9.18 \pm 4.1(b)$ & $43.38 \pm 5.6(\mathrm{ab})$ & $31.62 \pm 4.09(\mathrm{ab})$ & $29.7 \pm 12.8(\mathrm{~b})$ & $46.42 \pm 6.82(\mathrm{ab})$ & $53.78 \pm 7.5(\mathrm{ab})$ & $7.9 \pm 8.8(\mathrm{c})$ & $0 \pm 3.9(\mathrm{~b})$ \\
\hline $\mathrm{O}_{3}$ & $17.09 \pm 4.1(\mathrm{ab})$ & $25.9 \pm 5.6(\mathrm{c})$ & $23.45 \pm 4.09(\mathrm{ab})$ & $52.18 \pm 12.8(\mathrm{ab})$ & $32.19 \pm 6.82(\mathrm{~b})$ & $33.02 \pm 7.5(\mathrm{~b})$ & $15.51 \pm 8.8(\mathrm{bc})$ & $2.64 \pm 3.9(b)$ \\
\hline $\mathrm{O}_{3}+\mathrm{V}$ & $22.75 \pm 4.1(\mathrm{a})$ & $39.91 \pm 5.6(\mathrm{abc})$ & $34.49 \pm 4.09$ (a) & $70.78 \pm 12.8(a)$ & $49.48 \pm 6.82(\mathrm{ab})$ & $53.84 \pm 7.5(\mathrm{ab})$ & $19.04 \pm 8.8(\mathrm{bc})$ & $2.33 \pm 3.9(\mathrm{~b})$ \\
\hline \multicolumn{9}{|l|}{72 hpi } \\
\hline A & $16.45 \pm 4.1(\mathrm{ab})$ & $51.07 \pm 5.6(\mathrm{a})$ & $33.33 \pm 4.09$ (a) & $49.09 \pm 12.8(\mathrm{ab})$ & $52.9 \pm 6.82(\mathrm{a})$ & $63.44 \pm 7.5(\mathrm{a})$ & $23.6 \pm 8.8(b c)$ & $9.22 \pm 3.9(\mathrm{ab})$ \\
\hline $\mathrm{V}$ & $8.35 \pm 4.1(b)$ & $35.72 \pm 5.6(\mathrm{abc})$ & $19.38 \pm 4.09(b)$ & $27.15 \pm 12.8(\mathrm{~b})$ & $33.41 \pm 6.82(\mathrm{ab})$ & $43.73 \pm 7.5(\mathrm{ab})$ & $19.61 \pm 8.8(\mathrm{bc})$ & $4.14 \pm 3.9(b)$ \\
\hline $\mathrm{O}_{3}$ & $18.67 \pm 4.1(\mathrm{ab})$ & $36 \pm 5.6(\mathrm{abc})$ & $25.53 \pm 4.09(\mathrm{ab})$ & $55.16 \pm 12.8(\mathrm{ab})$ & $40.65 \pm 6.82(\mathrm{ab})$ & $43.30 \pm 7.5(\mathrm{ab})$ & $50.31 \pm 8.8(\mathrm{a})$ & $19.61 \pm 3.9(\mathrm{a})$ \\
\hline $\mathrm{O}_{3}+\mathrm{V}$ & $16.12 \pm 4.1(\mathrm{ab})$ & $36.11 \pm 5.6(\mathrm{abc})$ & $23.32 \pm 4.09(a b)$ & $43.11 \pm 12.8(\mathrm{ab})$ & $33.10 \pm 6.82(\mathrm{ab})$ & $37.62 \pm 7.5(b)$ & $35.56 \pm 8.8(\mathrm{ab})$ & $10.53 \pm 3.9(\mathrm{ab})$ \\
\hline
\end{tabular}

\footnotetext{
${ }^{a}$ Student $t$-test analysis of flavonoid accumulation in soybean leaves in response to elevated $\mathrm{O}_{3}$, Soybean mosaic virus $(\mathrm{SMV})$ and $\mathrm{O}_{3}$ plus $\mathrm{SMV}_{\text {treatments }}$ at 8 and $72 \mathrm{hpi}$. The values represent least square means \pm standard error. Within the column, the values with the same letter do not differ significantly $(P<$ $0.05)$.
} 
Several soybean $\mathrm{CHS}$ transcripts (CHS1, CHS2, CHS3, CHS5, CHS6, and CHS7/8) accumulate during the basal defense and HR to pathogens (Lozovaya et al. 2007; Zou et al. 2005). Although avirulent strains elicit a faster gene expression response than virulent strains, induction of $P A L$ and $C H S$ genes are observed in both interactions. Zabala and associates (2006) concluded that the synthesis of lignin or suberin is one of the early responses to the bacterial infection because of high accumulation of $C A D$ transcripts $2 \mathrm{~h}$ after $P$. syringae inoculation.

Elevated $\mathrm{O}_{3}$ or elevated $\mathrm{O}_{3}$-and-SMV combination treatments induced genes coding for key regulatory enzymes in the biosynthesis of flavonoids, causing changes in the concentrations of genistein, kaempherol, quercetin, and methyl quercetin derivatives in soybean leaves. Genistein and its more complex isoflavonoid derivatives exhibit broad spectrum antimicrobial activity. They can function as preformed "phytoanticipins" and inducible "phytoalexins" against pathogens (Dixon and Ferreira 2002). The increase in genistein malonyl hexose concentration may have contributed to defense against SMV. Moreover, preexposure to $\mathrm{O}_{3}$ prevented the decrease in methylquercetin triglycoside caused by SMV infection and induced the biosynthesis of kaempherol diglycoside (Table 3). External application of quercetin and derivatives effectively inhibited systemic infection of Potato virus $X$ (PVX) and Tomato ringspot virus (TomRSV) up to $70 \%$ (French and Towers 1992; Malhotra et al. 1996). Methylated quercetin compounds reduced infectivity of TMV, exposing the viral RNA to attack by host RNase by weakening virion subunit binding (French 1991). Increase in the kaempherol and quercetin derivatives by long-term elevated $\mathrm{O}_{3}$ treatment was part of a nonspecific host defense response but the defense was transient. As a response to elevated $\mathrm{O}_{3}$, soybean flavonoid concentrations increased at the beginning of the field season; however no, change was detected after July 14, 2005 (B. F. O'Neill, unpublished). Long-term $\mathrm{O}_{3}$ treatment may cause plants to acclimate to environmental conditions.

Several nucleotide binding site leucine-rich repeat family genes were upregulated by elevated $\mathrm{O}_{3}$; however, the overall defense response did not resemble a pathogen-specific response because it was transient. The main driving force for the induction of defense-related genes could have been excess ROS production under elevated $\mathrm{O}_{3}$. The events triggered were similar to SAR following HR response. The defense genes that showed an increase in transcript levels functioned downstream in an incompatible interaction and SAR, such as EDS1 and SGT1.

Transcripts homologous to a large number of $N A C$ TFs (negative regulators of PR genes) were decreased by elevated $\mathrm{O}_{3}$ and the combination of $\mathrm{O}_{3}$ plus SMV. Overexpression of Arabidopsis ATAF2, a member of the NAC-domain TF family, increased the susceptibility of transgenic plants to fungal infection (Delessert et al. 2005). A short period of acute $\mathrm{O}_{3}$ treatment induced the transcription of an NAM-like gene (At5g63790) in Arabidopsis (Mahalingam et al. 2006) but sustained levels of exposure to $\mathrm{O}_{3}$ downregulated the transcription of 15 NAC TFs in mature soybean plants (Table 2). By contributing to greater expression of $P R 1, P R 5$, and $P R 10$, the inhibition of $N A C$ s by $\mathrm{O}_{3}$ would enhance resistance to SMV. Also, $N A C$ TFs regulate various basic cellular processes, including cell division, secondary cell wall synthesis, and auxin-dependent formation of lateral roots (Kim et al. 2006; Xie et al. 2000; Zhong et al. 2006). Transcription of NAC TFs is regulated by microRNA (Mallory et al. 2004), and two of the soybean NAC genes that are downregulated had a potential miR164 complementary site with one mismatch (Table 2).

Vigorous ROS production by SMV was detected in ORAC assay with field samples and confirmed by histochemical staining in growth chambers. Susceptible soybean plants produced $\mathrm{H}_{2} \mathrm{O}_{2}$ in response to SMV infection, and the location and inten- sity of production were dependent on the strength of the infection (Fig. 2B). Although total ORAC increased with time and viral infection, it was not affected by elevated $\mathrm{O}_{3}$ under field conditions. Plants in natural field conditions are subjected to other stresses, including herbivory, drought, and heat, that cause sustained production of ROS. The production of ROS in response to other stresses may have masked its response to elevated $\mathrm{O}_{3}$ in the field. The production of ROS by elevated $\mathrm{O}_{3}$ was milder than ROS production following SMV infection (Fig. 2B through D). The spatial distribution of $\mathrm{H}_{2} \mathrm{O}_{2}$ accumulation was very different between treatments. $\mathrm{H}_{2} \mathrm{O}_{2}$ levels increased as SMV infection spread throughout the plant; on the other hand, superoxide production was the greatest when more than one stress was applied. This suggests different roles for ROS species.

Although elevated $\mathrm{O}_{3}$ induced temporary defense against SMV infection, it also affects photosynthesis and yield (Morgan et al. 2004, 2006). Elevated O3 reduces soybean photosynthesis during the vegetative stage and affects yield in some cultivars. Production of ROS may contribute to reduced photosynthesis and growth in elevated $\mathrm{O}_{3}$. Excess ROS improves resistance against various pathogens but causes damage as well. Acute doses of $\mathrm{O}_{3}$ exposure induce $\mathrm{HR}$ and cell death (Pasqualini et al. 2003). The major difference between ROS induced by plant-pathogen interactions and the effect of elevated $\mathrm{O}_{3}$ is that, during plant-pathogen interactions, ROS is generated initially under controlled conditions as a defense to restrict the pathogen, whereas exposure to elevated $\mathrm{O}_{3}$ induces ROS in an uncontrolled and widespread manner (Fig. 2).

In nature, plants rapidly lose their resistance as pathogens evolve to overcome their defenses (Roossinck 2003). Once inside the host cell, viral populations explode and vast numbers greatly increase the opportunity to develop new avenues of attack. A rapidly growing population of wild-type bacteriophage in a chemostat acquired adaptive traits in 180 days (Wichman et al. 2005). Growth in elevated $\mathrm{O}_{3}$ induced a nonspecific defense response against SMV; however, this defense was active for a limited time only. Although the increase in SMV population was retarded by elevated $\mathrm{O}_{3}$ (Table 1), the virus ultimately overcame nonspecific defenses mounted by soybean and caused a substantial reduction in final biomass. The strong positive selection promotes the rapid evolution of defense strategies on both sides. Thus, soybean has gone through several genetic bottlenecks because of domestication (Hyten et al. 2006) and may be limited in developing counterstrategies against viruses in the long term.

To our knowledge, this study is the first global gene expression analysis of soybean-SMV interaction. SMV infection caused differential regulation of 830 transcripts, of these 219 were unique to SMV treatment. The majority of these genes coded for proteins with unknown functions. SMV infection suppressed expression of several KTI gene expressions, possibly, as part of its infection strategy. KTIs function in plant defense response and their expression increases in response to herbivory, drought, and exogenous application of ABA, ET, and methyl jasmonate (Kang et al. 2002). Similarly, TF MYB6 (TC204916) was downregulated at early hours of the SMV infection. Cucumber mosaic virus (CMV) infection downregulates MYB TFs in Arabidopsis (Marathe et al. 2004). The downregulation of TF $M Y B 6$ could be because of viral dominance on the host transcription. This small cluster of genes was uniquely regulated by SMV infection and the genes were different from the nonspecific resistance genes initiated by elevated $\mathrm{O}_{3}$ and $\mathrm{O}_{3}$-and-SMV combination treatments.

\section{Concluding remarks.}

Elevated $\mathrm{O}_{3}$ altered gene expression in soybean and induced a nonspecific defense response. Although the host defense re- 
sponse was not induced specifically to stop SMV infection but to cope with the environmental changes, it retarded the replication and spread of the host-dependent pathogen temporarily. The induced nonspecific defense has multiple components. Transcriptional increases of PR genes and ET, SA, and JA signaling genes contributed to the defense response to a certain degree. The increase in flavonoid biosynthesis genes and the increase in several flavonoids indicated that flavonoid biosynthesis was one of the major players in the nonspecific defense response.

These stress-induced plant responses may change predisposition and enhance tolerance for a second stress factor. Many preformed and induced defense systems against pathogens involve activation of the same or overlapping signaling pathways with abiotic stresses. At the early stages of the stress, the induction of genes involved in a signal transduction pathway is often specific to the particular stimulus. However, downstream events involving stress adaptation are orchestrated by the same genes across different types of stress factors. The number of differentially regulated soybean genes that were common in response to all stresses increased from 30 to $50 \%$ over time. Therefore, biotic and abiotic signaling pathways may share multiple nodes and their outputs may have significant functional overlap.

The dynamics of plant-pathogen interactions are shaped by a complex set of ecological and evolutionary influences. The altered molecular and physiological state of the plant influenced its interaction with the virus. The changes in the preformed defenses and the strength of induced defenses will affect the arms race between plants and pathogens, and future changes in the composition of the atmosphere may alter the coevolution of plants and pathogens.

\section{MATERIALS AND METHODS}

\section{Field experiment.}

Soybean plants (G. $\max$ cv. 93B15; Pioneer Hi-Bred, Des Moines, IA, U.S.A.) were exposed to elevated $\mathrm{O}_{3}$ and infected with SMV under natural field conditions. Plants were grown in large plots $\left(314 \mathrm{~m}^{2} / \mathrm{plot}\right)$ at the University of Illinois Soybean Free-air Concentration Enrichment facility (SoyFACE), where atmospheric levels of $\mathrm{O}_{3}$ were precisely controlled. Each experimental plot $(n=4)$ was surrounded by pipes that injected $\mathrm{O}_{3}$ at supersonic velocity from $300-\mu \mathrm{m}$ pores above the canopy. The rate and position of gas release was automatically altered with wind speed and direction to maintain the desired gas concentrations. Plots were fumigated during daylight hours from planting until harvest. The target concentration for $\mathrm{O}_{3}$ (1.2× ambient; $8 \mathrm{~h} \mathrm{O}_{3}, 59.8 \mathrm{nmol} \mathrm{mol}^{-1}$ ) represents the predicted atmospheric levels by 2050. Cross-contamination between treatments was prevented by separating the experimental plots by at least $100 \mathrm{~m}$. Dermody and associates (2006) provide a more detailed description of the SoyFACE facility.

The SoyFACE experiment included fully replicated plots exposing plants to elevated $\mathrm{CO}_{2}\left(550 \mu \mathrm{mol} \mathrm{mol}^{-1}\right)$ during daylight hours from planting until harvest. Measurements of SMV infection, antioxidant capacity, and photosynthesis for plants exposed to elevated $\mathrm{CO}_{2}$ were included in the statistical analysis applied to the data in Table 1 (full factorial analysis of variance).

The crop was planted on day of the year (DOY) 145 in 2005; on DOY 189, 16 plants in each experimental plot were randomly selected and the mature fourth trifoliates of 8 plants were rub-infected with SMV-G2 as in Chen and associates (2004). Another set of eight randomly selected plants was mock inoculated. The inoculums were prepared by grinding previously SMV-infected (for SMV inoculation) and noninfected (for mock treatment) G. max cv. Williams leaves in chilled 0.025 M potassium phosphate buffer ( $\mathrm{pH} 7.1$ ), $0.01 \mathrm{M}$ sodium sulfite, and Carborundum (320 grit).
Each experiment was conducted as four biological replicates (plots), and each replicate consisted of a pooled sample from four plants. In addition to measurements of gas exchange, final biomass, and yield, samples were collected from inoculated leaves 8 and 72 hpi for RNA isolation.

\section{DAS-ELISA.}

For quantitative analysis of virus accumulation, samples from top leaves were collected at 7, 14, 21, and 28 days postinfection (dpi). Detection of SMV coat protein was carried out following the standard procedures for DAS-ELISA assay as described in the manufacturer's protocol (PathoScreen Kit; Agdia, Elkhart, IN, U.S.A.). The results were expressed as RFU measured at an optical density of $405 \mathrm{~nm}$ on a plate reader (EL 340; Bio-Teck Services Inc., Richmond, VA, U.S.A.). Four biological replicates and two technical replicates were processed for each treatment. Separate samples from inoculated leaves were collected at $8 \mathrm{hpi}$ and were analyzed quantitatively to determine the initial amount of infection.

\section{Antioxidant capacity assay.}

To assess total ORAC (Cao et al. 1993) of soybean leaves, disks ( $1.5 \mathrm{~cm}$ in diameter) were collected at 7, 14, and $21 \mathrm{dpi}$, flash frozen in liquid nitrogen, and stored at $-80^{\circ} \mathrm{C}$ until analysis. Four disks collected from top leaves of four inoculated (SMV-G2 or mock) plants were pooled for each biological replicate and there were four replicates per treatment. Samples (1 $\mathrm{mg}$ ) were ground in a bead beater at room temperature, extracted with acidic acetonitrile, and resuspended in methanol (1 $\mathrm{ml}$ ) before analysis as described by Lee and associates (2004). The final mixture for assay contained a 1:1,000 dilution of the

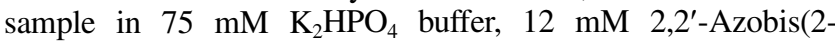
amidino-propane)dihydrochloride), and $70.3 \mathrm{nM}$ fluorescein (Huang et al. 2002). Fluorescence was measured at $530 \mathrm{~nm}$ with excitation at $485 \mathrm{~nm}$ using a 96-well plate fluorimeter (Synergy HT; Bio-Tek Instruments, Inc., Winooski, VT, U.S.A.).

Gas-exchange and chlorophyll fluorescence measurements. Light-saturated rates of carbon assimilation $\left(\mathrm{A}_{\text {sat }}\right)$ were measured on infected and noninfected plants with an openpath gas-exchange system (LI-6400, LI-COR, Inc., Lincoln, NE, U.S.A.) at 4, 8, 16, 22, and 41 dpi. Four infected and four control plants were measured on each day in each experimental plot. The leaf immediately above the one inoculated with the virus and the corresponding leaf on control plants were measured. The portion of the leaflet inside the gas-exchange cuvette was maintained at 29 to $30^{\circ} \mathrm{C}$ (50\% relative humidity) and $\mathrm{CO}_{2}$ at $400 \mu \mathrm{mol} \mathrm{mol}{ }^{-1}$ in the reference air stream for the ambient and elevated $\mathrm{O}_{3}$ treatments. Photon flux density at the leaf surface was the maximum PFD determined in the field above the canopy (LI-190; LI-COR, Inc.) on the date of each measurement $\left(2000 \mu \mathrm{mol} \mathrm{m} \mathrm{m}^{-2} \mathrm{~s}^{-1}\right.$ for days $4,8,22$, and $41 ; 800$ $\mu \mathrm{mol} \mathrm{m} \mathrm{m}^{-2} \mathrm{~s}^{-1}$ for day 16). Carbon assimilation rates were light saturated with PFD above $700 \mu \mathrm{mol} \mathrm{m}^{-2} \mathrm{~s}^{-1}$ (data not shown).

\section{Biomass and leaf-area measurements.}

The aboveground portions of a subset of infected and control plants ( $n=5$ each) in each plot were harvested on DOY 227 and separated into leaves, stems, and pods. Total leaf area for the harvested plants in each experimental plot was measured with a leaf-area meter (LI-3100C; LI-COR, Inc.). The tissue was then dried to constant mass $\left(60^{\circ} \mathrm{C}\right)$ and weighed.

\section{Statistical analysis of field experiment.}

Variables measured (DAS-ELISA, ORAC, gas exchange, and biomass) in the field experiment were evaluated by fullfactorial ANOVA (Proc Mixed, SAS 9.1; SAS Institute Inc., 
Cary, NC, U.S.A.). To control for topographic and soil variations among the FACE plots, a priori blocks were included as random effects in the gas exchange statistical analyses. Measurements performed on multiple dates were analyzed in a repeated design (with day as the repeated factor) in an autoregressive covariance structure. Statistical significance was considered for $P \leq 0.05$. For gas exchange and biomass results, post-hoc multiple comparisons were conducted using the Tukey-Kramer adjustment.

\section{Growth chamber experiment.}

To further explore the interactions between SMV and $\mathrm{O}_{3}$, the same soybean cultivar as the field experiment was maintained in two growth chambers at 27 and $22^{\circ} \mathrm{C}$ and a photoperiod of 16 and $8 \mathrm{~h}$ of light and darkness, respectively, with an irradiance of $500 \mu \mathrm{mol} \mathrm{m}{ }^{-2} \mathrm{~s}^{-1}$ (PFD). In one chamber, plants were exposed from germination to $\mathrm{O}_{3}$ at $90 \pm 5 \mathrm{nmol} \mathrm{mol}^{-1}$ for $8 \mathrm{~h}$ /day using an $\mathrm{O}_{3}$ generator (Model HTU-500AC; Azco Industries Ltd., Surrey, British Columbia, Canada) and analyzer (Model 1008-RS; Dasibi Environmental Corp., Glendale, CA, U.S.A.). Another cohort of plants was grown in a nearby growth chamber under the same environmental conditions, except air was charcoal filtered to remove ambient $\mathrm{O}_{3}$. Plants and treatments were rotated between chambers weekly to minimize potential "chamber effects". When plants developed one mature third trifoliate (approximately 3 weeks after germination), half of the plants in each chamber were randomly selected and were rub infected with SMV-G2 strain as described previously. The remaining half of the plants were mock inoculated as controls. For each treatment and sampling timepoint, four biological replicates were created. For each biological replicate, four plants were pooled.

Samples were collected from SMV- and mock-inoculated leaves at 8 and 72 hpi for measurement of global gene expression by microarray. The 8-hpi sampling timepoint was selected to detect the early response of genes involved in signaling and cellular communication and the 72-hpi timepoint was selected to monitor the genes involved in defense responses, metabolic adaptation, and protein translation and modifications.

\section{RNA isolation and microarray hybridization.}

The total RNA was isolated with an isolation procedure optimized for high-polysaccharide-containing soybean leaves. For each biological replicate, the trifoliate collected from four plants was pooled and flash frozen in liquid nitrogen. The frozen leaves were ground in precooled mortars with liquid nitrogen until they became fine powder. For $1 \mathrm{~g}$ of tissue, $4 \mathrm{ml}$ of homogenization buffer (38\% acidic phenol, $0.4 \mathrm{M}$ ammonium thiocyanate, $0.8 \mathrm{M}$ guanidine thiocyanate, $0.1 \mathrm{M}$ of $3 \mathrm{M}$ sodium acetate [pH 5.5], and 5\% glycerol) was added. The mixture was transferred to Phase Lock Gel-Heavy (PLG) (Brinkmann Instruments, Inc., Westbury, NY, U.S.A.) and one-fifth volume of chloroform was added. The tubes were centrifuged for $10 \mathrm{~min}$ at $2,000 \times \mathrm{g}$. The aqueous phase was transferred to a new PLG tube and equal volumes of phenol/chloroform/ isoamylalcohol $(5: 4: 1)$ and cold, $3 \mathrm{M}$ potassium acetate, $\mathrm{pH}$ 5.5 ( $1 \mathrm{ml}$ of potassium acetate per $3 \mathrm{ml}$ of aqueous phase) were added. The mixture was left on ice for $1 \mathrm{~h}$ and centrifuged for $10 \mathrm{~min}$ at $2,000 \times \mathrm{g}$. The aqueous phase was transferred to a clean centrifuge tube. Sodium citrate $(0.8$ $\mathrm{M})$ /sodium chloride (1.2 M) salt mixture was added ( 0.25 volume) and the RNA was precipitated with 0.25 volume of ethanol for $30 \mathrm{~min}$ at $-20^{\circ} \mathrm{C}$. The concentration of samples was determined with a NanoDrop ND-1000 spectrophotometer (NanoDrop Technologies, Wilmington, DE, U.S.A.) and was verified with a BioAnalyzer 2100 (Agilent Technologies, Palo Alto, CA, U.S.A.).
Target preparation was performed according to the manufacturer's protocol (Affymetrix, Inc., Santa Clara, CA, U.S.A.). RNA from four biological replications for each treatment and mock-inoculated control was hybridized to oligonucleotide microarrays (Affymetrix GeneChip; Affymetrix) for measurement of global gene transcription. Hybridization and scanning were performed at the W. M. Keck Center for Comparative and Functional Genomics, University of Illinois at Urbana-Champaign, Urbana, IL, U.S.A.

\section{Statistical analysis of microarray data and clustering.}

The microarray data from four biological replicates for each timepoint from the growth chamber experiment were analyzed. Raw data were background corrected with Robust Multi-chip Average in the BioConductor affy module for R. The background-corrected and log-transformed perfect match intensities were normalized using the quantile normalization method developed by Bolstad and associates (2003). The normalized data were analyzed statistically using SAS (v9.1.2; SAS Institute Inc.) by the following ANOVA model:

$$
\begin{gathered}
y_{i j k l m}=\mu+P_{i}+O_{j}+V_{k}+T_{l}+(P O)_{i j}+(P v)_{i k}+(P T)_{i l}+ \\
(O V)_{j k}+(O T)_{j l}+(V T)_{k l}+(O V T)_{j k l}+\varepsilon_{i j k l m}
\end{gathered}
$$

where $\mu$ is the overall mean, $y_{i j k l m}$ is the PM-logarithm of the $m$ th replicate model-based-expression value at the $i$ th probe gene $(i=1, \ldots, 11), j$ th treatment $(j=1,2), k$ th virus $(k=1,2)$, and $l$ th time $(l=1,2) ; P$, probe set; $O$, elevated $\mathrm{O}_{3} ; V$, virus; and $T$, time. Significant gene lists were obtained after applying a cutoff FDR of $<0.01$, which was calculated based on the $P$ value from the ANOVA as in Benjamini and Hochberg (1995) using SAS.

\section{Gene annotation.}

The Affymetrix oligonucleotide-based GeneChip Soybean Genome Array is prepared from the available expressed sequence tag sequences consisting of 37,593 probe sets representing 35,611 soybean transcripts. This chip does not fully represent the soybean genome because it is not yet sequenced. To understand the possible function of individual transcripts, we compared the sequence used by Affymetrix to The Institute for Genomic Research soybean gene indices tentative consensus (TC) and NCBI nonredundant sequences and Arabidopsis sequences.

\section{Quantitative RT-PCR analysis.}

The expression level of two PR genes $(P R-10$ and $P R-5)$ and a small subunit of ribulose bisphosphate carboxylase gene (Rubisco SSII) were measured by quantitative RT-PCR for infected plants grown under elevated $\mathrm{O}_{3}$ in growth chambers and elevated $\mathrm{O}_{3}$ and $\mathrm{CO}_{2}$ in the field experiment. Primers were designed using Primer 3 software (Rozen and Skaletsky 2000). Total RNA from leaf samples was extracted as described above and was enriched for mRNA using affinity columns (QIATEX; Qiagen, CA, U.S.A.). cDNA was synthesized from $20 \mathrm{ng}$ of mRNA using Superscript III (Invitrogen, Carlsbad, CA, U.S.A.). Serial dilutions up to $1 \times 10^{4}$ of the cDNA were used in a standard real-time RT-PCR reaction containing Sybergreen dye to determine reaction efficiencies for each primer set and sample. Based on calculated PCR efficiencies, 0.2 to 2.0 ng of mRNA equivalent cDNA was used to monitor changes in transcript level. A dissociation curve analysis was performed and confirmed the absence of multiple amplification products prior to relative gene expression analysis. Data were normalized to the expression level of actin 3 isoform B (TC204824), an endogenous, constitutively expressed reference gene, and relative gene expression was calculated according to Pfaffl and associates (2002). 
Analysis of flavonoids with LC/MS.

For each timepoint and treatment, there were three biological replicates. For each biological replicate, the infected or mock-treated leaves from four plants were pooled and freeze dried for 2 days. Lyophilized tissue $(50 \mathrm{mg}$ ) was weighed and placed in a 2-ml microcentrifuge tube. A glass bead $(6 \mathrm{~mm})$ was placed into the same tube and the tissue was shaken in a Qiagen bead beater for 2 min until it became a fine powder. To the powder sample, $500 \mu \mathrm{l}$ of extraction buffer (9 parts methanol and 10 parts $0.5 \%$ formic acid, with $0.001 \%$ xanthotoxol as an internal standard) was added. The samples were placed on a shaker for $30 \mathrm{~min}$ at room temperature and thoroughly mixed; then, the samples were spun for $30 \mathrm{~s}$ at maximum speed $(14,000 \mathrm{rpm})$ in a microcentrifuge. The supernatant was transferred to a $1.5 \mathrm{ml}$-microcentrifuge tube containing $50 \mathrm{mg}$ of C-18 silica, which removed highly nonpolar compounds. The sample was vortexed briefly and spun for $30 \mathrm{~s}$ at maximum speed $(14,000 \mathrm{rpm})$ in a microcentrifuge. The supernatant (approximately $200 \mu \mathrm{l}$ ) was transferred to a microinsert tube inside a 2-ml glass autosampler vial. Sample (10 $\mu \mathrm{l})$ was injected into the Shimadzu 2010 spectrometer for LC/MS and was analyzed by Shimadzu Labsolutions software. The LC/MS separation was performed using a Luna C18 column (250-by2-mm column, $5-\mu \mathrm{m}$ particle size) at $25^{\circ} \mathrm{C}$. The LC/MS eluents were aqueous $0.05 \%$ formic acid (A) and acetonitrile (B). The initial gradient condition was $90 \% \mathrm{~A}$ and $10 \% \mathrm{~B}$, changing linearly to $70 \% \mathrm{~B}$ in $48 \mathrm{~min}$. After analysis, the column was equilibrated for $17 \mathrm{~min}$ at initial conditions, giving a total analysis time of $65 \mathrm{~min}$. The eluent flow rate was $0.2 \mathrm{ml} / \mathrm{min}$. To identify some of the flavonoids with the same base mass of charge $(\mathrm{m} / \mathrm{z})$, acid hydrolysis was performed. In all, $20 \mu \mathrm{l}$ of 2 $\mathrm{N} \mathrm{HCl}$ was added to $150 \mu \mathrm{l}$ of extract and boiled for $60 \mathrm{~min}$ in an airtight vial. As a control instead of $\mathrm{HCl}, 20 \mu \mathrm{l}$ of high-performance liquid chromatography-grade water was added to the extract. Both extracts were analyzed by LC/MS with the conditions previously described. To identify compounds, several standards were used as references. The standard solutions were prepared by dissolving $564 \mu \mathrm{g}$ of daidzein, $81 \mu \mathrm{g}$ of daidzin, $72 \mu \mathrm{g}$ of genistin, $232 \mu \mathrm{g}$ of glycitin, $292 \mu \mathrm{g}$ of kaempherol, $266 \mu \mathrm{g}$ of kaempherol-3-O-glucoside, $224 \mu \mathrm{g}$ of luteolin-7-Oglucoside, $140 \mu \mathrm{g}$ of quercitrin, $281 \mu \mathrm{g}$ of quercetin, and 427 $\mu \mathrm{g}$ of rutin in $3 \mathrm{ml}$ of methanol. The standards $(10 \mu \mathrm{l})$ were injected into the spectrometer for LC/MS analysis.

The variables measured were evaluated by full-factorial ANOVA (Proc Mixed, SAS 9.1; SAS Institute Inc.). Statistical significance $(P<0.05)$ of paired least square means was compared by using Student's $t$ test.

\section{DAB and NBT staining.}

Elevated $\mathrm{O}_{3}$ induces oxidative stress and mimics the effect of biotic elicitors. To determine whether $\mathrm{O}_{3}$ and SMV elicited similar responses in soybean leaves, the spatial and temporal distribution of ROS was examined by histochemical staining.

In a separate controlled-environment experiment, plants were exposed to elevated $\mathrm{O}_{3}$ with and without SMV infection. One group of plants was grown from germination in a chamber with $\mathrm{O}_{3}$ at $90 \pm 5 \mathrm{nmol} \mathrm{mol}{ }^{-1}$ for $8 \mathrm{~h} /$ day. Another group of plants was grown in ambient conditions and half of the plants in each chamber were challenged with SMV. DAB was used to determine hydrogen peroxide $\left(\mathrm{H}_{2} \mathrm{O}_{2}\right)$ and NBT for superoxide $\left(\mathrm{O}_{2}{ }^{--}\right)$accumulation as described by Fryer and associates (2002). DAB forms a dark brown precipitate upon reacting with $\mathrm{H}_{2} \mathrm{O}_{2}$ in the presence of peroxidase. When NBT reacts with $\mathrm{O}_{2}{ }^{\bullet-}$, a dark blue insoluble formazan is produced. To avoid the wound-induced ROS production from rubbing inoculated leaves with Carborundum and to observe the differences in the systemic infection of SMV, the fourth fully developed trifoliate (above the infected leaf) was stained 1 and 2 weeks postinfection. Tissues were boiled in destaining solution that contained glycerol, lactic acid, acidic phenol, ethanol, and water (1:1:1:2:1 parts) to remove chlorophyll. Leaves were imaged under a stereo microscope (SZX12; Olympus, Center Valley, PA, U.S.A.) and digital camera (DP70; Olympus). Although these dyes have low specificity, they are widely used to verify oxidative stress in plants (Shulaev and Oliver 2006).

\section{ACKNOWLEDGMENTS}

We thank G. Hartman for providing SMV-G2 strain; H. Hobbs, W. Yi, N. Gloude, E. Weldon, B. Berla, and A. Lee for their assistance with the field experiments; W. M. Keck Center for Comparative and Functional Genomics staff for their expertise in Affymetrix GeneChip hybridizations; $M$. Bilgin for critical reading of the manuscript; and members of the Genomic Ecology of Global Change research theme at Institute for Genomic Biology, University of Illinois at Urbana-Champaign for their help and valuable suggestions throughout the study. This research was supported by the Office of Science (BER), U.S. Department of Energy, Grant no. DEFG02-04ER63489.

\section{LITERATURE CITED}

Ahlfors, R., Lang, S., Overmyer, K., Jaspers, P., Brosche, M., Tauriainen, A., Kollist, H., Tuominen, H., Belles-Boix, E., Piippo, M., Inze, D., Palve, E. T., and Kangasjarvi, J. 2004. Arabidopsis RADICALINDUCED CELL DEATH1 belongs to the WWE protein-protein interaction domain protein family and modulates abscisic acid, ethylene, and methyl jasmonate responses. Plant Cell 16:1925-1937.

Ainsworth, E. A., and Rogers, A. 2007. The response of photosynthesis and stomatal conductance to rising [CO2]: Mechanisms and environmental interactions. Plant Cell Environ. 30:258-270.

Apel, K., and Hirt, H. 2004. Reactive oxygen species: Metabolism, oxidative stress, and signal transduction. Annu. Rev. Plant. Biol. 55:373-399.

Ashmore, M. R., Buker, P., Emberson, L. D., Terry, A. C., and Toet, S. 2007. Modeling stomatal ozone flux and deposition to grassland communities across Europe. Environ. Pollut. 146:659-670.

Baker, B., Zambryski, P., Staskawicz, B., and Dinesh-Kumar, S. P. 1997. Signaling in plant-microbe interactions. Science 276:726-733.

Baulcombe, D. 2004. RNA silencing in plants. Nature 431:356-363.

Benjamini, Y., and Hochberg, Y. 1995. Controlling the false discovery rate: A practical and powerful approach to multiple testing. J. R. Stat. Soc. Ser. B 57:289-300.

Bernacchi, C. J., Leakey, A. D., Heady, L. E., Morgan, P. B., Dohleman, F. G., McGrath, J. M., Gillespie, K. M., Wittig, V. E., Rogers, A., Long, S. P., and Ort, D. R. 2006. Hourly and seasonal variation in photosynthesis and stomatal conductance of soybean grown at future $\mathrm{CO}_{2}$ and ozone concentrations for 3 years under fully open-air field conditions. Plant Cell Environ. 29:2077-2090.

Bilgin, D. D., Liu, Y., Schiff, M., and Dinesh-Kumar, S. P. 2003. P58(IPK), a plant ortholog of double-stranded RNA-dependent protein kinase PKR inhibitor, functions in viral pathogenesis. Dev. Cell 4:651661.

Bolstad, B. M., Irizarry, R. A., Astrand, M., and Speed, T. P. 2003. A comparison of normalization methods for high density oligonucleotide array data based on variance and bias. Bioinformatics 19:185-193.

Bolwell, G. P., Bindschedler, L. V., Blee, K. A., Butt, V. S., Davies, D. R., Gardner, S. L., Gerrish, C., and Minibayeva, F. 2002. The apoplastic oxidative burst in response to biotic stress in plants: A three-component system. J. Exp. Bot. 53:1367-1376.

Brown, J. E., Khodr, H., Hider, R. C., and Rice-Evans, C. A. 1998. Structural dependence of flavonoid interactions with $\mathrm{Cu} 2$ ions: Implications for their antioxidant properties. Biochem. J. 330:1173.

Byrne, K. 2001. Human impact. Page 179 in: Environmental Science (Anonymous). Nelson Thornes, Cheltenham, U.K.

Campbell, S. J. 2007. Ozone injury in west coast forests: 6 years of monitoring. General Technical Report. Pacific Northwest Research Station, USDA Forest Service, Portland, OR, U.S.A.

Cao, G., Alessio, H. M., and Cutler, R. G. 1993. Oxygen-radical absorbance capacity assay for antioxidants. Free Radic. Biol. Med. 14:303-311.

Chen, J., Zheng, H. Y., Lin, L., Adams, M. J., Antoniw, J. F., Zhao, M. F., Shang, Y. F., and Chen, J. P. 2004. A virus related to soybean mosaic virus from Pinellia ternata in China and its comparison with local soybean SMV isolates. Arch. Virol. 149:349-363.

Chen, W., Provart, N. J., Glazebrook, J., Katagiri, F., Chang, H. S., Eulgem, T., Mauch, F., Luan, S., Zou, G., and Whitham, S. A. 2002. 
Expression profile matrix of Arabidopsis transcription factor genes suggests their putative functions in response to environmental stresses. Plant Cell 14:559-574.

Chiron, H., Drouet, A., Lieutier, F., Payer, H. D., Ernst, D., and Sandermann, H., Jr. 2000. Gene induction of stilbene biosynthesis in Scots pine in response to ozone treatment, wounding, and fungal infection. Plant Physiol. 124:865-872.

Cushman, J. C., and Bohnert, H. J. 2000. Genomic approaches to plant stress tolerance. Curr. Opin. Plant Biol. 3:117-124.

Delessert, C., Kazan, K., Wilson, I. W., Van Der Straeten, D., Manners, J., Dennis, E. S., and Dolferus, R. 2005. The transcription factor ATAF2 represses the expression of pathogenesis-related genes in Arabidopsis. Plant J. 43:745-757.

Dermody, O., Long, S. P., and DeLucia, E. H. 2006. How does elevated $\mathrm{CO}_{2}$ or ozone affect the leaf-area index of soybean when applied independently? New Phytol. 169:145-155.

Dixon, R. A., and Ferreira, D. 2002. Genistein. Phytochemistry 60:205

Dodd, I. C. 2003. Hormonal interactions and stomatal responses. J. Plant Growth Regul. 22:32-46.

Durrant, W. E., and Dong, X. 2004. Systemic acquired resistance. Annu. Rev. Phytopathol. 42:185-209.

French, C. J. 1991. Flavonoids inhibit infectivity of Tobacco mosaic virus. Can. J. Plant Pathol. 13:1.

French, C. J., and Towers, G. H. N. 1992. Inhibition of infectivity of potato virus $\mathrm{X}$ by flavonoids. Phytochemistry 31:3017.

Fryer, M. J., Oxborough, K., Mullineaux, P. M., and Baker, N. R. 2002. Imaging of photo-oxidative stress responses in leaves. J. Exp. Bot. 53:1249-1254.

Gadjev, I., Vanderauwera, S., Gechev, T. S., Laloi, C., Minkov, I. N., Shulaev, V., Apel, K., Inze, D., Mittler, R., and Van Breusegem, F. 2006. Transcriptomic footprints disclose specificity of reactive oxygen species signaling in Arabidopsis. Plant Physiol. 141:436-445.

Gard, E. E., Kleeman, M. J., Gross, D. S., Hughes, L. S., Allen, J. O., Morrical, B. D., Fergenson, D. P., Dienes, T., E Galli, M., Johnson, R. J., Cass, G. R., and Prather, K. A. 1998. Direct observation of heterogeneous chemistry in the atmosphere. Science 279:1184-1187.

Heagle, A. S., McLaughlin, M. R., Miller, J. E., and Joyner, R. L. 1992. Response of two white clover clones to Peanut stunt virus and ozone. Phytopathology 82:254-258.

Heath, R. L. 2007. Alterations of the biochemical pathways of plants by the air pollutant ozone: Which are the true gauges of injury? Sci. World J. 7:110-118.

Houghton, J. T., Ding, Y., Griggs, D. J., Noguer, M., van der Linden, P. J., Dai, X., Maskell, K., and Johnson, C. A., eds. 2001. Climate change 2001: The scientific basis. Cambridge University Press, Cambridge.

Huang, D., Ou, B., Hampsch-Woodill, M., Flanagan, J. A., and Prior, R. L. 2002. High-throughput assay of oxygen radical absorbance capacity (ORAC) using a multichannel liquid handling system coupled with a microplate fluorescence reader in 96-well format. J. Agric. Food Chem. 50:4437-4444.

Hyten, D. L., Song, Q., Zhu, Y., Choi, I. Y., Nelson, R. L., Costa, J. M. Specht, J. E., Shoemaker, R. C., and Cregan, P. B. 2006. Impacts of genetic bottlenecks on soybean genome diversity. Proc. Natl. Acad. Sci. U.S.A. 103:16666-16671

Kachroo, A., and Kachroo, P. 2007. Salicylic acid-, jasmonic acid- and ethylene-mediated regulation of plant defense signaling. Genet. Eng. 28:55-83.

Kang, S. G., Choi, J. H., and Suh, S. G. 2002. A leaf-specific 27 kDa protein of potato Kunitz-type proteinase inhibitor is induced in response to abscisic acid, ethylene, methyl jasmonate, and water deficit. Mol. Cells 13:144-147.

Kangasjarvi, J., Jaspers, P., and Kollist, H. 2005. Signaling and cell death in ozone-exposed plants. Plant Cell Environ. 28:1021-1036.

Kanofsky, J. R., and Sima, P. D. 2000. Assay for singlet oxygen generation by plant leaves exposed to ozone. Methods Enzymol. 319:512-520.

Kim, Y. S., Kim, S. G., Park, J. E., Park, H. Y., Lim, M. H., Chua, N. H., and Park, C. M. 2006. A membrane-bound NAC transcription factor regulates cell division in Arabidopsis. Plant Cell 18:3132-3144.

Korkina, L. G. 1997. Antioxidant and chelating properties of flavonoids. Adv. Pharmacol. 38:151.

Korkina, L. G. 2007. Phenylpropanoids as naturally occurring antioxidants: From plant defense to human health. Cell. Mol. Biol. 53:15.

Kotchoni, S. O., and Gachomo, E. W. 2006. The reactive oxygen species network pathways: An essential prerequisite for perception of pathogen attack and the acquired disease resistance in plants. J. Biosci. 31:389404

Krupa, S. V. 2003. Joint effects of elevated levels of ultraviolet-B radiation, carbon dioxide and ozone on plants. Photochem. Photobiol. 78:535-542.

Langebartels, C., Ernst, D., Kangasjarvi, J., and Sandermann, H., Jr. 2000. Ozone effects on plant defense. Methods Enzymol. 319:520-535.
Lee, J., Finn, C. E., and Wrolstad, R. E. 2004. Comparison of anthocyanin pigment and other phenolic compounds of Vaccinium membranaceum and Vaccinium ovatum native to the Pacific Northwest of North America. J. Agric. Food Chem. 52:7039-7044.

Lee, S. C., Choi, H. W., Hwang, I. S., Choi du, S., and Hwang, B. K. 2006. Functional roles of the pepper pathogen-induced bZIP transcription factor, CAbZIP1, in enhanced resistance to pathogen infection and environmental stresses. Planta 224:1209-1225.

Leon, P., and Sheen, J. 2003. Sugar and hormone connections. Trends Plant Sci. 8:110-116.

Li, P., Mane, S. P., Sioson, A. A., Robinet, C. V., Heath, L. S., Bohnert, H. J., and Grene, R. 2006. Effects of chronic ozone exposure on gene expression in Arabidopsis thaliana ecotypes and in Thellungiella halophila. Plant Cell Environ. 29:854-868.

Lozovaya, V. V., Lygin, A. V., Zernova, O. V., Ulanov, A. V., Li, S., Hartman, G. L., and Widholm, J. M. 2007. Modification of phenolic metabolism in soybean hairy roots through down regulation of chalcone synthase or isoflavone synthase. Planta 225:665-679.

Lucas, W. J., and Lee, J. Y. 2004. Plasmodesmata as a supracellular control network in plants. Nat. Rev. Mol. Cell Biol. 5:712-726.

Lucas, W. J., Bouche-Pillon, S., Jackson, D. P., Nguyen, L., Baker, L., Ding, B., and Hake, S. 1995. Selective trafficking of KNOTTED1 homeodomain protein and its mRNA through plasmodesmata. Science 270:1980-1983.

Luthen, H., Botther, M., and Schenck, D. 2007. Receptors for the five classical plant hormones. Pages 221-241 in: Progress in Botany, vol. 68. K. Esser, U. E. Luttge, W. Beyschlag, and J. Murata, eds. Springer. Berlin.

Mahalingam, R., Jambunathan, N., Gunjan, S. K., Faustin, E., Weng, H., and Ayoubi, P. 2006. Analysis of oxidative signaling induced by ozone in Arabidopsis thaliana. Plant Cell Environ. 29:1357-1371.

Malhotra, B., Onyilagha, J. C., Bohm, B. A., Towers, G. H. N., James, D., Harborne, J. B., and French, C. J. 1996. Inhibition of tomato ringspot virus by flavonoids. Phytochemistry 43:1271.

Mallory, A. C., Dugas, D. V., Bartel, D. P., and Bartel, B. 2004. MicroRNA regulation of NAC-domain targets is required for proper formation and separation of adjacent embryonic, vegetative, and floral organs. Curr. Biol. 14:1035-1046.

Manning, W. J., and V Tiedemann, A. 1995. Climate change: Potential effects of increased atmospheric carbon dioxide $\left(\mathrm{CO}_{2}\right)$, ozone $\left(\mathrm{O}_{3}\right)$, and ultraviolet-B (UV-B) radiation on plant diseases. Environ. Pollut. $88: 219-245$.

Mano, J. 2002. Early events in environmental stresses in plants-Induction mechanism of oxidative stress. Pages 217-245 in: Oxidative Stress in Plants. D. Inze and M. Van Montagu, eds. Taylor and Francis Group, London.

Marathe, R., Guan, Z., Anandalakshmi, R., Zhao, H., and Dinesh-Kumar, S. P. 2004. Study of Arabidopsis thaliana resistome in response to cucumber mosaic virus infection using whole genome microarray. Plant Mol. Biol. 55:501-520

Mazarei, M., Elling, A. A., Maier, T. R., Puthoff, D. P., and Baum, T. J. 2007. GmEREBP1 is a transcription factor activating defense genes in soybean and Arabidopsis. Mol. Plant-Microbe Interact. 20:107-119.

Mittler, R. 2006. Abiotic stress, the field environment and stress combination. Trends Plant Sci. 11:15-19.

Morgan, P. B., Bernacchi, C. J., Ort, D. R., and Long, S. P. 2004. An in vivo analysis of the effect of season-long open-air elevation of ozone to anticipated 2050 levels on photosynthesis in soybean. Plant Physiol. 135:2348-2357.

Morgan, P. B., Mies, T. A., Bollero, G. A., Nelson, R. L., and Long, S. P. 2006. Season-long elevation of ozone concentration to projected 2050 levels under fully open-air conditions substantially decreases the growth and production of soybean. New Phytol. 170:333-343.

Mudd, J. B. 1998. Biochemical reactions of ozone in plants. USDA For. Serv. Gen. Tech. Rep. 166:3-10.

Ogawa, D., Nakajima, N., Tamaoki, M., Aono, M., Kubo, A., Kamada, H. and Saji, H. 2007. The isochorismate pathway is negatively regulated by salicylic acid signaling in $\mathrm{O}_{3}$-exposed Arabidopsis. Planta 226:1277-1285.

Overmyer, K., Brosche, M., Pellinen, R., Kuittinen, T., Tuominen, H., Ahlfors, R., Keinanen, M., Saarma, M., Scheel, D., and Kangasjarvi, J. 2005. Ozone-induced programmed cell death in the Arabidopsis radical-induced cell death1 mutant. Plant Physiol. 137:1092-1104.

Park, C. J., Kim, K. J., Shin, R., Park, J. M., Shin, Y. C., and Paek, K. H. 2004. Pathogenesis-related protein 10 isolated from hot pepper functions as a ribonuclease in an antiviral pathway. Plant J. 37:186-198.

Pasqualini, S., Piccioni, C., Reale, L., Ederli, L., Della Torre, G., and Ferranti, F. 2003. Ozone-induced cell death in tobacco cultivar Bel W3 plants. The role of programmed cell death in lesion formation. Plant Physiol. 133:1122-1134.

Pfaffl, M. W., Horgan, G. W., and Dempfle, L. 2002. Relative expression software tool (REST) for group-wise comparison and statistical analysis 
of relative expression results in real-time PCR. Nucleic Acids Res. 30:e36.

Pietta, P. G. 2000. Flavonoids as antioxidants. J. Nat. Prod. 63:1035-1042.

Rao, M. V., and Davis, K. R. 1999. Ozone-induced cell death occurs via two distinct mechanisms in Arabidopsis: The role of salicylic acid. Plant J. 17:603-614

Rao, M. V., and Davis, K. R. 2001. The physiology of ozone induced cell death. Planta 213:682-690.

Rao, M. V., Koch, J. R., and Davis, K. R. 2000a. Ozone: A tool for probing programmed cell death in plants. Plant Mol. Biol. 44:345-358.

Rao, M. V., Lee, H., Creelman, R. A., Mullet, J. E., and Davis, K. R. 2000b. Jasmonic acid signaling modulates ozone-induced hypersensitive cell death. Plant Cell 12:1633-1646.

Rao, M. V., Lee, H. I., and Davis, K. R. 2002. Ozone-induced ethylene production is dependent on salicylic acid, and both salicylic acid and ethylene act in concert to regulate ozone-induced cell death. Plant J. 32:447-456.

Roossinck, M. J. 2003. Plant RNA virus evolution. Curr. Opin. Microbiol. 6:406-409.

Rozen, S., and Skaletsky, H. 2000. Primer3 on the WWW for general users and for biologist programmers. Methods Mol. Biol. 132:365-386.

Sandermann, H., Jr. 1996. Ozone and plant health. Annu. Rev. Phytopathol. $34: 347$.

Sandermann, H., Jr. 2000. Active oxygen species as mediators of plant immunity: Three case studies. Biol. Chem. 381:649-653.

Scheel, D. 2002. Oxidative burst and role of reactive oxygen species in plant-pathogen interaction. Pages 137-153 in: Oxidative Stress in Plants. D. Inze and M. Van Montagu, eds. Taylor and Francis, London and New York.

Schraudner, M., Langebartels, C., and Sandermann, H., Jr. 1996. Plant defence systems and ozone. Biochem. Soc. Trans. 24:456-461.

Schubert, R., Fischer, R., Hain, R., Schreier, P. H., Bahnweg, G., Ernst, D., and Sandermann, H., Jr. 1997. An ozone-responsive region of the grapevine resveratrol synthase promoter differs from the basal pathogenresponsive sequence. Plant Mol. Biol. 34:417-426.

Shadle, G. L., Wesley, S. V., Korth, K. L., Chen, F., Lamb, C., and Dixon, R. A. 2003. Phenylpropanoid compounds and disease resistance in transgenic tobacco with altered expression of L-phenylalanine ammonia-lyase. Phytochemistry 64:153-161.

Sharma, Y. K., Leon, J., Raskin, I., and Davis, K. R. 1996. Ozone-induced responses in Arabidopsis thaliana: The role of salicylic acid in the accumulation of defense-related transcripts and induced resistance. Proc. Natl. Acad. Sci. U.S.A. 93:5099-5104.

Shulaev, V., and Oliver, D. J. 2006. Metabolic and proteomic markers for oxidative stress. New tools for reactive oxygen species research. Plant Physiol. 141:367-372.

Singh, K., Foley, R. C., and Onate-Sanchez, L. 2002. Transcription factors in plant defense and stress responses. Curr. Opin. Plant Biol. 5:430-436.
Sohn, K. H., Lee, S. C., Jung, H. W., Hong, J. K., and Hwang, B. K. 2006. Expression and functional roles of the pepper pathogen-induced transcription factor RAV1 in bacterial disease resistance, and drought and salt stress tolerance. Plant Mol. Biol. 61:897-915.

Tian, L., Pang, Y., and Dixon, R. A. Biosynthesis and genetic engineering of proanthocyanidins and (iso)flavonoids. Phytochem. Rev. In press.

Tosti, N., Pasqualini, S., Borgogni, A., Ederli, L., Falistocco, E., Crispi, S., and Paolocci, F. 2006. Gene expression profiles of $\mathrm{O}_{3}$-treated Arabidopsis plants. Plant Cell Environ. 29:1686-1702.

Tuominen, H., Overmyer, K., Keinanen, M., Kollist, H., and Kangasjarvi, J. 2004. Mutual antagonism of ethylene and jasmonic acid regulates ozone-induced spreading cell death in Arabidopsis. Plant J. 39:59-69.

Ursini, F., Maiorino, M., Morazzoni, P., Roveri, A., and Pifferi, G. 1994. A novel antioxidant flavonoid (IdB 1031) affecting molecular mechanisms of cellular activation. Free Radic. Biol. Med. 16:547-553.

Whitham, S. A., Quan, S., Chang, H. S., Cooper, B., Estes, B., Zhu, T., Wang, X., and Hou, Y. M. 2003. Diverse RNA viruses elicit the expression of common sets of genes in susceptible Arabidopsis thaliana plants. Plant J. 33:271-283.

Wichman, H. A., Millstein, J., and Bull, J. J. 2005. Adaptive molecular evolution for 13,000 phage generations: A possible arms race. Genetics 170:19-31.

Wildermuth, M. C., Dewdney, J. Wu, G., and Ausubel, F. M. 2001 Isochrismate synthase is required to synthesize salicylic acid for plant defence. Nature 414:562-565.

Xie, Q., Frugis, G., Colgan, D., and Chua, N. H. 2000. Arabidopsis NAC1 transduces auxin signal downstream of TIR1 to promote lateral root development. Genes Dev. 14:3024-3036.

Yamaguchi-Shinozaki, K., and Shinozaki, K. 2006. Transcriptional regulatory networks in cellular responses and tolerance to dehydration and cold stresses. Annu. Rev. Plant. Biol. 57:781-803.

Zabala, G., Zou, J., Tuteja, J., Gonzalez, D. O., Clough, S. J., and Vodkin, L. O. 2006. Transcriptome changes in the phenylpropanoid pathway of Glycine max in response to Pseudomonas syringae infection. BMC Plant Biol. 6:26.

Zhong, R., Demura, T., and Ye, Z. H. 2006. SND1, a NAC domain transcription factor, is a key regulator of secondary wall synthesis in fibers of Arabidopsis. Plant Cell 18:3158-3170.

Zou, J., Rodriguez-Zas, S., Aldea, M., Li, M., Zhu, J., Gonzalez, D. O., Vodkin, L. O., DeLucia, E., and Clough, S. J. 2005. Expression profiling soybean response to Pseudomonas syringae reveals new defenserelated genes and rapid HR-specific downregulation of photosynthesis. Mol. Plant-Microbe Interact. 18:1161-1174.

\section{AUTHOR-RECOMMENDED INTERNET RESOURCE}

SoyFACE website: www.soyface.uiuc.edu 